Şalk, S., Köroğlu, Ö. / Journal of Yasar University, 2020, 15/58, 313-328

\title{
Turist Rehberlerinin Artırılmış Gerçeklik Uygulamalarına Yönelik Algılarının Belirlenmesi ${ }^{1}$
}

\section{Determining of Tourist Guides' Perceptions Towards Augmented Reality Applications}

\author{
Semih ŞALK, Balıkesir Üniversitesi, Türkiye, semihsalk1 @ gmail.com \\ Orcid No: 0000-0002-8911-325X \\ Özlem KÖROĞLU, Balıkesir Üniversitesi, Türkiye, ozlemkoroglu_98@yahoo.com \\ Orcid No: 0000-0002-3974-6120
}

\begin{abstract}
Öz: Artırılmış gerçeklik uygulamalarının kullanımı, müzelerdeki sergileme yöntemlerinin zenginleştirilmesi ve kültürel miras alanlarında yer alan kültürel öğelerin korunması ve turistlerin bu öğeleri daha iyi bir biçimde anlașllmasını sağlaması açısından oldukça önemli olmaktadır. Turist rehberlerinin mesleklerini icra ederken, anlatımlarını destekleyebilecek ve hizmet kalitelerini arttırmaların sağlayabilecek artırlmıs gerçeklik uygulamaların kullanmaları, turistlerin anlatılan konularla ilgili daha iyi bir düzeyde bilgi alabilmelerini sağlamakla birlikte, turlarını ilgi çekici bir deneyim haline getirmektedir. Bu doğrultuda, turist rehberlerinin artırlmış gerçeklik uygulamalarına yönelik algl düzeylerinin belirlenmesi bu çalışmanın temel amacını oluşturmaktadır. Araștırmanın verileri, yarı yapılandırılmış görüşme formu aracıllğıyla, turist rehberleri ile yapılan yüz yüze ve telefon görüsmeleri ile elde edilmistir. Nitel bir arastırma olarak tasarlanan bu çalısmada, fenomenolojik arastirma deseni kapsamında betimsel analiz tekniği kullanılmıştır. Araştırmaya dahil edilen 100 turist rehberi arasından yalnızca 22 turist rehberinin artırılmış gerçeklik uygulamaları ile ilgili bilgi sahibi olması nedeniyle, ilgili turist rehberlerinin görüsleri değerlendirmeye alınabilmiștir. Bu doğrultuda, turist rehberleri arasında artırılmış gerçeklik uygulamalarının bilinirlik düzeyinin düşük olduğu sonucuna ulaşılmıştır. İlgili turist rehberleri, artırllmış gerçeklik uygulamalarının turlar süresince kullanımının önemli olduğuna değinmekle birlikte, turist rehberlerine ve turistlere olumlu yönde etkileri bulunacağına değinmislerdir. Turlar süresince kullanılan artırlmıs gerçeklik uygulamalarının yetersiz sayıda olması, dolaylsıyla turist rehberlerinin bu uygulamalar yeterli düzeyde deneyimleyememesi sebebiyle, rehberlerin artırlmış gerçeklik uygulamalarına yönelik memnuniyet düzeylerinin ve tavsiye etme oranlarının düşük olduğu düşünülmektedir.
\end{abstract}

Anahtar Sözcükler: Turist Rehberi, Teknoloji, Artırlmıı̧ Gerçeklik, Algl

JEL Sinfflandirmasl: L83, L86, O30

\begin{abstract}
The use of augmented reality applications is important in terms of enriching the display methods in museums and preserving cultural elements in the cultural heritage areas and ensuring that tourists are better understood. The use of augmented reality applications that can support tourist guides and improve their quality of service while performing their profession, makes the tour a compelling experience, while providing tourists with a better level of information on the subjects described. In this context, the main purpose of this study is to determine the perception levels of tourist guides towards augmented reality applications. The data of the study was obtained by face-to-face and telephone interviews with tourist guides through semistructured interview form. In this study, which is designed as a qualitative research, descriptive analysis technique is used within the scope of phenomenological research design. Since only 22 tourist guides from 100 tourist guides included in the study were informed about augmented reality applications, the views of the relevant tourist guides could be evaluated. In this respect, it is concluded that the awareness level of augmented reality applications is low among tourist guides. Relevant tourist guides mentioned that the use of augmented reality applications during tours is important, but also stated that there will be positive effects on tourist guides and tourists. Because of the inadequate number of augmented reality applications used during the tours, and therefore the tourist guides cannot experience these applications sufficiently, it is thought that the guides have low levels of satisfaction and recommended rates for augmented reality applications.
\end{abstract}

Keywords: Tourist Guide, Technology, Augmented Reality, Perception

JEL Classification: L83, L86, O30

\section{Giriş}

Teknolojik gelişmelerin, üretim, ticaret, sağlık, yayıncılık, turizm ve eğlence gibi tüm ekonomiyi; eğitimin bütün evrelerini; siyaset ve kamu yönetimi gibi kısacası yaşamın tüm boyutlarını değiştirdiği görülmektedir. Teknoloji, bilim, bilgisayar ve iletişim alanındaki gelişmeler ile birlikte bilginin oluşturulması, saklanması, düzenlenmesi, işlenmesi, taşınması, hizmete sunulması ve kullanılmasını sağlayan sistemler bilgi teknolojileri olarak adlandırılmaktadır (Devlet Planlama Teşkilatı [DPT] 2001, 1). Turizm ve seyahat olgusunun ham maddesinin bilgi olmasından dolayı, turistik hizmeti sunanlar tarafindan ürün ve hizmetlerin tanıtımı, tüketiciler tarafindan ise istek ve gereksinimlerinin tatmin edilmesi, mevcut bilgilerin ne derecede başarılla sunulabildiğine bağl olmaktadır. Bu sebeple turizm sektörü, bilgi teknolojilerinin en yaygın biçimde kullanıldığı alanlardan birisi olmaktadır (Sarı ve Kozak 2005, 249-250).

\footnotetext{
${ }^{1}$ Bu makale, Semih Şalk’ın “Turist Rehberlerinin Artırılmış Gerçeklik Uygulamalarına Yönelik Algılarının Belirlenmesi” adlı yüksek lisans tezinden hazırlanmıştır. İlgili yüksek lisans tezi, Balıkesir Üniversitesi Rektörlüğü Bilimsel Araştırma Projeleri Birimi tarafindan BAP 2017/07 kodlu proje ile desteklenmiştir.
}

Makale Gecmiși / Article History

Başvuru Tarihi / Date of Application

Kabul Tarihi / Acceptance Date

: 15 Mayıs / May 2019

: 12 Aralık / December 2019 
Teknolojik gelişmelerin kullanımı konusunda turistler, yalnızca tatillerini geçirdiği süre içerisinde değil; tatillerine karar verme aşamasından, tatil sonrası geri bildirim aşamalarına kadar her alanda teknolojik iletişim kanallarından faydalanmaktadırlar (Çakmak ve Demirkol 2017, 222). Örneğin, turistler gitmek istedikleri destinasyonlar hakkında bilgileri, web tabanlı siteler ve çeşitli uygulamalar aracılığıyla önceden alabilmektedirler. Turistlerle birebir etkileşimde bulunan turist rehberlerinin de anlatımlarına destekleyici nitelikte olan teknolojik uygulamaları kullanmaları, etkili tanıtım yapabilmelerinin yanında hizmet kalitelerini arttırmalarını sağlamaktadır (Tekin ve diğerleri 2017, 296-302).

Günümüzde görsel teknoloji uygulamalarının, müzeler gibi kültürel alanlarda kullanılan envanter ve belgeleme uygulamaları üzerindeki etkisi ön plana çıkmaktadır. Genel olarak bilgi verme, iletişim ve deneyim kazandırma amaçlı kullanılan müze teknolojilerinin, bilgi işletim sistemleri ve bu sistemler ile kullanılan teknolojik cihazların yaygınlaşması ile birlikte geniş bir uygulama alanı kazandığ görülmektedir (Boyraz 2013, 115). Geçtiğimiz yıllarda, kültürel miras alanlarında kullanılmak üzere videolar ve kiosklar gibi ziyaretçilerin tarihi, sanatsal ve diğer konularda etkileşimli bilgi almalarını sağlayan bilgisayar teknolojilerine yer verilmiştir. Ancak bu teknolojilerin çoğu, etkileşimli görsellerin bir kısmını çözdüğü gibi rehberlik, navigasyon bilgileri, bilginin kişiselleştirilmesi, depolanan nesnelere erişim ve animasyonlar gibi pek çok özellikten yoksun olmaktadır (Vlahakis ve diğerleri 2002, 52). Bu sebeple, artırılmış gerçeklik teknolojisi gibi uygulamalar aracılığıyla bu tür eksikliklerin kapatılması amaçlanmaktadır. Artırılmış gerçeklik uygulamaları, müze ve ören yerlerindeki bulunan eserlerin günümüz ve eski orijinal halini, gerçek ortam üzerine ekran, dijital kamera, GPS, kablosuz bağlantı ve çeşitli cihazlar aracılığıyla bilgisayar tarafindan oluşturulan 3 boyutlu görüntülerin yansıtılarak, ziyaretçilerin zihinlerinde canlandırmalarına ve karşılaştırmalarına olanak sağlayan teknolojilerdir (Harmankaya 2010, 14). Bununla birlikte, artırılmış gerçeklik uygulamalarının eserlerin eski ve orijinal hallerinin karşılaştırılmasının yanında, bu eserlerin gerçek görüntü üzerine eş zamanlı olarak interaktif bilgi alınabilmesini sağlayan varyasyonları da bulunmaktadır.

Artırılmış gerçeklik uygulamaları ile ilgili alanyazın taraması sonucunda, turistik alanlarda bu teknolojilerin kullanımının ziyaretçilerin seyahatlerini ilgi çekici bir deneyim haline getirdiği (Höllerer ve Feiner 2004); üç boyutlu nesneler, metin veya resim gibi sanal açıklamalarla, ziyaretçilerin eserleri gerçek ortamda varmış gibi algılamalarını sağlayıp (Styliani ve diğerleri 2009) müze sergisinin ziyaretçi üzerindeki etkisini arttırdığı (Wojciechowski ve diğerleri 2004); ziyaretçilerin arkeolojik alanların geçmişini bu uygulamalar aracılığıyla daha iyi anlaşılmasına yardımcı olarak memnun kalmalarını sağladığı (Vlahakis ve diğerleri 2002) görülmektedir. Bu tür teknolojiler, turist rehberlerinin anlatımlarını desteklenmesi sağlayarak hizmet kalitelerini arttırmakta (Tekin ve diğerleri 2017), bunun sonucunda da turistlerin turdan memnun olarak ayrılmalarını sağlamaktadır. Turist rehberleri sahip oldukları bilgileri, kültürel anlayışları ve iletişim becerileri ile turist ziyaretlerini turdan deneyime dönüştüren kişilerdir (Köroğlu 2013). Turist rehberleri, sahip oldukları bilgileri doğrudan aktarmalarından ziyade, anlatımlarını yorumlama yoluyla zenginleştirip turistlerin zihinlerinde canlandırabilecek bir şekilde yapmaları büyük önem taşımaktadır (Güzel 2007). Bu doğrultuda, turistlerin farklı bir deneyimle birlikte tatmin olmalarını ve turist rehberlerinin de daha iyi bir tanıtım yaparak hizmet kalitelerinin artırılmasını sağlayabilecek artırılmış gerçeklik uygulamalarının, turist rehberleri tarafından nasıl algılandığı bu çalışmanın amacını oluşturmaktadır.

\section{Literatür}

Turist rehberlerinin gezilen destinasyonlar ve kültür hakkında bilgi ve yorumlamaları, hizmet ve iletişim becerilerinin yanında, turist ziyaretlerini deneyime dönüştürmektedir (Tetik 2006, 20). Turist rehberleri, turistlerin ziyaretleri sürecinde eşlik ederek seyahat organizasyonunu kolaylaştırmakta, gezilen destinasyonlar hakkında doğru bilgiler vererek, seyahatlerin mümkün olduğunca sorunsuz ve zevkli geçmesini sağlamaktadır. Turist rehberleri bu rollerini gerçekleştirirken bir yandan turistlerin ziyaret deneyimlerindeki memnuniyet ya da memnuniyetsizlik düzeyini belirlerken diğer yandan verdikleri bilgi, beceri, tutum ve davranışlarıyla da temsil ettikleri ülkenin imajını yansıtan bir model oluşturmaktadırlar. Turistlerin ziyaret ettikleri ülkeden memnun ve olumlu bir izlenimle ayrılması, turizm sektöründe gelişim ve istikrarın sağlanması açısından büyük önem taşımaktadır (Kuşluvan ve Çeşmeci 2002, 235-236).

Turist rehberlerinin, turistlerin deneyimlerinin arttırılmasında ve bir destinasyonun ve kültürünün anlaşılmasında yorumlayıcı rolü büyük önem arz etmektedir. Bilgileri, kültürel anlayışları ve iletişim becerileri ile turist rehberleri, turistlerin ziyaretlerini turdan deneyime dönüştüren kişiler olmaktadırlar (Köroğlu 2013, 107). Turist rehberlerinin yorumlamalarının başarısında ziyaret edilen yerlere tutku ve sempati beslemesi, anlatımlarını hikayelerle birlikte canlandırması ve mizah duygusuna sahip olması oldukça etkilidir. Turist rehberleri, anlatılan doğal ve kültürel konular ile turistler arasında denge kurmalı ve sunumlarını turistlerin zihni ile bağdaştırabilme becerisine sahip olmalıdır. Çünkü bilgi kullanılan malzemelerden yalnızca birisi olduğundan, yorumlama yoluyla bilginin açıklığa kavuşturulması gerekli olmaktadır (Güzel 2007, 23-24). Bu doğrultuda, turist rehberlerinin sahip olduğu bilgileri olduğu gibi turistlere aktarmalarından ziyade, anlatımlarını hikayeler, plan, harita, çizim, fotoğraf ve teknolojik cihazların kullanımı gibi görsel materyallerle zenginleştirerek yorumlamalarının oldukça önemli olduğu söylenebilir.

\subsection{Turist Rehberliği ve Teknoloji İlişkisi}

Teknolojide yaşanan hızlı gelişmelerle birlikte, turist rehberliği hizmetinin yalnızca turist rehberlerinin anlatımlarıyla birlikte değil, çeşitli teknolojik cihazlar (akıllı telefon uygulamaları gibi) aracılığıyla da yapıldığı görülmektedir. Bu teknolojilerin kullanımı, turist rehberlerinin çalışma alanı çeşitlerine göre değişkenlik gösterebilmektedir (Tekin ve diğerleri 2017, 294). 
Ahipaşaoğlu (2006), turist rehberlerini statik ve profesyonel turist rehberi olmak üzere iki grupta incelemiştir. Statik rehberler müzeler, ören yerleri, ülke ya da destinasyonlar ve ulaşım yollarını kapsayan ve daha çok kendi gezisini yönetmek isteyen kişilere yönelik, sesli rehberlik hizmetlerini, foto-rehber kitapları, broşür ve kataloglar ile ses ve görüntü kayıtlarını içermektedir. Müzeler ve ören yerlerinde kullanılan turist rehberliği ile ilişkilendirilebilecek teknolojilerin interaktif yüzey sistemleri, e-kataloglar, üç boyutlu hologramlar, sanal asistanlar, şeffaf lcd vitrin uygulamaları, şeffaf projeksiyon filmleri, sanal objeler, video mapping ve artırılmış gerçeklik (Dönmezoğlu 2013); sesli rehberlik cihazları, etkileşimli kiosklar, cep bilgisayarları (PDA) ve cep telefonları (Harmankaya 2010); sanal müze uygulamaları, simülasyonlar ve projeksiyonlar (Boyraz 2013) gibi uygulamalar olduğu söylenebilir.

Turist rehberlerinin kullandığı araçlar, gereçler ve ekipmanlar, Mesleki Yeterlilik Kurumu'nun (MYK) 16.07.2010 tarihli ve 27643 sayılı Resmi Gazete'de yayınlanan Profesyonel Turist Rehberi (Seviye 5) Ulusal Meslek Standardı'nda belirtilmiştir. $\mathrm{Bu}$ araç, gereç ve ekipmanlar arasında ajanda, bilgisayar, el feneri, fotoğraf makinesi, gerekli telefonlar rehberi, GPS cihazı, harita, hesap makinesi, iletişim araçları (telsiz, telefon gibi), kamera, pusula ve sözlük gibi teknolojiler ve malzemeler yer almaktadır (Mesleki Yeterlilik Kurumu 2010).

Akıllı telefonların, indirilebilen ve çalıştırılabilen pek çok uygulamayla birlikte kullanımı giderek yaygınlaşmaktadır (Zhou ve diğerleri 2011, 93). Pence (2010), küresel konumlama sistemi (GPS), kamera, pusula, ivmeölçer, WiFi desteği ve web tarayıcılarını bir cihazda birleştiren akıllı telefonları, modern iletişimin çok fonksiyonlu bir İsviçre çakısı olarak tanımlamaktadır. Satış segmenti hızla büyüyen akıllı telefonlar, dünyanın dört bir yanındaki insanlar tarafından neredeyse her yerden kablosuz olarak bir ağa bağlanılmasını sağlayan bir bilgisayar olarak kullanılmaktadır (Johnson, Levine, Smith ve Stone 2010, 9). Bununla birlikte akıllı telefonlar, telefon rehberleri, mesajlaşma, web tarayıcısı, e-posta, hava durumu verileri, alarm, kronometre, zamanlayıc1, hesap makinesi, takvim, ajanda, not defteri, kamera, GPS navigasyonu ve el feneri gibi pek çok fonksiyonların bir arada bulunduğu bir teknolojidir (http://www.pcmag.com). Bu doğrultuda, turist rehberline yönelik Ulusal Meslek Standardı'nda belirtilen araç, gereç ve ekipmanların birçoğunun, akıllı telefonlar sayesinde tek bir cihazda toplanmasının turist rehberlerine büyük kolaylık sağladığı söylenebilir.

Mobil turist rehberlerinin son y1llarda turistlerin ziyaret ettikleri alanlarda kullanımı gittikçe yaygınlaşmaktadır (Kenteris ve diğerleri 2011, 97). Sesli rehberlik cihazları, cep bilgisayarları (PDA) ya da cep telefonları gibi teknolojiler mobil rehberlik sistemlerine örnek olarak verilebilir. Sesli rehberlik cihazları, en çok rağbet gören elektronik rehberlik sistemlerinden biri olup, müzeler, sergiler, kongreler gibi birçok alanda bu cihazların kullanımına rastlanılmaktadır. İlk olarak çıktıklarında adres defteri, takvim ve ajanda gibi işlevleri bulunan cep bilgisayarları (PDA), günümüzde akıllı telefonlar haline gelmişlerdir. Akıllı telefonlar gerekli uygulamaların yüklü olmasıyla birlikte, kameraları aracılığıyla görüntüleri tanımlayabilmekte ve artırılmış gerçeklik uygulamalarında ses kaydı ve video oynatabilme fonksiyonlarıyla sesli rehberlikte kullanılabilmektedir. Akıllı telefonlar, turistlerin GPS teknolojisi ile birlikte konumlarını belirleyerek turistlere rehberlik edebilmektedirler (Harmankaya 2010, 16-21).

Turist rehberlerinin yanında, turistler de yeni teknolojilerin kullanımı benimsemektedir (Tekin ve diğerleri 2017, 296). Özellikle küçük gruplarda, bir turist rehberi eşliğinde gezi düzenlemenin maliyetli olacağı düşünüldüğünden, bu kişiler kendi başlarına gezmeyi ve nokta rehberlik hizmetlerinden faydalanmayı tercih etmektedirler (Ahipaşaoğlu 2006, 116). Diğer yandan, mobil turist rehberlerinin tercih edilen dilden açıklama yapabilmesi ve kişilerin kendi gezilerini düzenlemelerine olanak sağlaması gibi güçlü yönlerinin yanında; cihaza soru sorulamaması, hayali canlandırma anlatımına yer verilememesi ve anlatımın tekdüze olması gibi zayıf yönleri bulunmaktadır. Turizm sektöründe önemli görevler üstlenen turist rehberlerinin yerine bu teknolojilerin kullanılması, turizmi kültürler arası etkileşimden uzaklaştırarak sosyal bir olay olmaktan çıkarmaktadır. Bu da turizm olayının yapısına aykırı bir durum olmaktadır (Köroğlu 2011, 217). Bu noktada mobil turist rehberlerinin, profesyonel turist rehberlerinin mesleki gelişimlerine yardımcı ve rehberli turlara destekte bulunan uygulamalar olarak değerlendirilmesi büyük önem taşımaktadır (Tekin ve diğerleri 2017, 303).

Çağdaş müzecilikte, müzedeki eserler ve ziyaretçiler arasında iletişimin kurulması oldukça önemlidir. Turist rehberleri eşliğindeki müze ziyaretlerinde, dia-film gösterilerinin izlenmesi, seminerlerin düzenlenmesi ve çeşitli eğitim uygulamalarının gerçekleştirilmesiyle geziler eğitici ve eğlendirici bir hale gelmektedir (Karatay 2015, 9). Yeni medya uygulamalarının, kültürel değerlerin yazılı, görsel ve işitsel yöntemlerle sergilenmesi ve kültürel mirasın korunmasının yanında, bu uygulamaların gerçek ve sanal platformda kullanıcılara ve araştırmacılara ulaştırılması için günümüz teknolojilerinin sağladığı imkanlar göz önünde bulundurulduğunda, oldukça önemli bir etkisi bulunmaktadır (Muşkara 2017, 97). Bu doğrultuda, müzelerde ve kültürel miras alanlarında kullanılan teknolojilere kiosklar, interaktif yüzey sistemleri, üç boyutlu hologramlar, şeffaf projeksiyon filmleri, şeffaf lcd vitrin uygulaması, sanal objeler, sanal asistan, e-kataloglar, planetaryumlar, interaktif inceleme sistemleri, arkeolojik kazı ve eşleme oyunları, arazi bilgi sistemi, sanal gerçeklik ve artırılmış gerçeklik örnek olarak verilebilir (Harmankaya 2010; Dönmezoğlu 2013; Boyraz 2013; Tekin ve diğerleri 2017). Sanal gerçekliğin bir varyasyonu olan artırılmış gerçeklik teknolojisi (Azuma 1997, 355), bilgisayar tarafından oluşturulan sanal görüntülerin gerçek dünya ortamının öğeleriyle birleştirilmesini sağlayan sistemlerdir (Milgram ve Kishino 1994, 3). Müzelerde bir sergileme yöntemi olarak kullanılan artırılmış gerçeklik uygulamaları, bu sistemlerde kullanılan teknolojik bileşenler aracılığıyla (kamera, görüntü tanıma gibi), bilgisayar ortamında yaratılan üç boyutlu nesneler, metin veya resim gibi sanal verilerin, ziyaretçiler tarafından gerçek ortamda varmış gibi algılanmasını sağlamaktadır (Styliani ve diğerleri 2009, 523). Ziyaretçilerin kültürel miras alanlarında artırılmış gerçeklik uygulamalarını kullanmalarıyla birlikte, o alanda bulunan kalıntıların ya da harabelerin renkli ekranlar, dijital kameralar, GPS, kablosuz bağlantı ve donanmış cihazlar yoluyla ilk yapıldıkları orijinal hallerinin görülüp, zihinlerinde canlandırmalarına aracılık etmektedir (Harmankaya 2010, 14). 


\subsection{Artırılmış Gerçeklik}

Artırılmış gerçeklik, sanal ortamların ya da daha yaygın adıyla sanal gerçekliğin bir varyasyonudur. Sanal gerçeklik teknolojileri, kullanıcılarını daha çok yapay bir ortama dahil ederken; artırılmış gerçeklik teknolojisi, gerçek dünya görüntüsüne üst üste bindirilen ya da bir araya getirilen yapay nesnelerle birlikte kullanıcılarının gerçek dünyayı görmelerini sağlamaktadır (Azuma 1997, 355). Sanal gerçekliğin temel amacı, teknolojiyi gerçekliğin yerine koymak iken, artırılmış gerçeklik, gerçekliği dijital içeriklerle artırmayı amaçlamaktadır (Billinghurst ve diğerleri 2014, 79). Diğer bir ifadeyle, artırılmış gerçeklik kullanıcılarını tamamen sanal bir dünyaya dahil etmek yerine; onları gerçek bir ortama ya da gerçek bir ortamın videosuna sanal verilerle dahil olmalarına çalışmaktadır (Bimber ve Raskar 2005, 2).

Artırılmış gerçeklik, sanal bilgisayar tarafindan oluşturulan görüntüler ile gerçek dünya ortamının öğelerini birleştiren gelişmiş bir teknolojidir (Milgram ve Kishino 1994, 3). Bilgisayar sistemlerinde üretilen enformasyonları fiziksel olarak içinde bulunulan çevre ile eş zamanlı ya da dolaylı olarak birleştiren uygulamalardır (Carmigniani ve Furth 2011, 3). Artırılmış gerçeklik, gerçek dünyada var olan nesneleri daha anlamlı ve çekici hale getirecek şekilde sanal tamamlayıcılarla birleştirerek, kullanıcılarının bu uygulamadaki gerçekliğe olan algılamalarını artırmaktadır (Zhu ve diğerleri 2004, 2). Zachary ve diğerleri (1997) artırılmış gerçekliği, bilgisayar tarafından üretilen ses, video, grafik ve küresel konumlama sistemi verileriyle, gerçek dünyadaki ortamı eş zamanlı, doğrudan ya da dolaylı olarak birleştirip zenginleştiren bir çalışma alanı olarak tanımlamaktadırlar.

Tüm bu tanımlamalara ek olarak, Azuma (1997), gerçek dünyayı, bilgisayar tarafindan üretilen sanal nesnelerle tamamlayan artırılmış gerçeklik sisteminde bulunması gereken özellikleri: gerçek ve sanal nesneleri gerçek bir ortamda birleştirmesi, gerçek zamanlı etkileşim sunması, gerçek ve sanal nesneleri birbirlerine uygun şekilde harmanlaması (üç boyutlu bir ortam sağlaması) şeklinde sıralamaktadır. Artırılmış gerçeklik, sanal nesnelerin ve gerçek dünya ortamının birleşimini ifade etmekte olduğundan; kullanıcılar, gerçek dünya ortamını keşfetmek için sanal nesneleri kullanarak gerçekçi bir illüzyon deneyimi yaşamaktadırlar (Kan ve diğerleri 2011, 340). Ayrıca gerçekliğin desteklenmesini ve güçlenmesini sağlayan artırılmış gerçeklik uygulamaları, sanal nesnelerin gerçek dünyaya aktarılmasının dışında dokunsal ve kokusal bilgileri de gerçek dünyadaki kullanıcıların algılamalarını sağlayarak, katılımcı bir deneyim imkânı oluşturmaktadır (Sayımer ve Küçüksaraç 2015, 1538).

Artırılmış gerçeklik, yıllardır gelişmekte ve günümüz modern teknolojik yapısına doğru ilerlemekte olan bir teknolojidir (Kipper ve Rampolla 2013, 14). Bu teknolojinin uygulamalarının ilk olarak askeri, endüstriyel ve sağlık alanlarında olmak üzere; eğitim, mimari, pazarlama, eğlence, turizm, müze ve ören yerleri gibi alanlarda kullanıldığ görülmektedir (Azuma ve diğerleri 2001; Bimber ve Raskar 2005; Van Krevelen ve Poelman 2010; Lee 2012; Bower ve diğerleri 2014; Billinghurst ve diğerleri 2014).

Turizmde kullanılan artırılmış gerçeklik uygulamaları, özellikle turistlerin gitmiş oldukları destinasyonlardaki yerlerin konumlarıyla birlikte, sanal eklentilerle bilgilendirilmelerini sağlayarak, seyahatlerini ilgi çekici bir deneyim haline getirmektedir (Höllerer ve Feiner 2004, 399). Han ve diğerleri (2014), konum tabanlı artırılmış gerçeklik cihazlarının, turistlere gezdikleri yerlerde rehberlik ederek, turizm sektörüne katkıda bulunacağına değinmektedirler. Bu cihazların kameraları aracılığıyla, gerçek dünya ortamının görüntüsü üzerine video, resim, metin veya sembol gibi sanal içeriklerin eklenerek; turistik mekanların, restoranların veya anıtların açıklanmaları sağlanmaktadır. Bu tür uygulamalarda WiFi noktaları, ATM'ler, otoparklar, ulaşım, yerel haberler ve hava durumu gibi bilgilerin yanında; çeşitli sosyal medya platformlarında kullanıcılar tarafından yapılan yorum, öneri ve değerlendirmeler de yer alabilmektedir (Yovcheva ve diğerleri 2012, 63). Bu tür uygulamalara örnek olarak, "Blippar" şirketinin 2017 y1lında duyurduğu, gezilen şehirler hakkında bilgi alınabilmesini sağlayan "CityAR" uygulaması verilebilir. Bu uygulama, akıllı telefonlar ya da tabletler aracılığıyla gerçek dünya görüntüsü üzerine sanal verileri yansıtarak, Londra ve San Francisco gibi dünya çapında 300’e yakın şehrin gezilmesine ve keşfedilmesine olanak tanımaktadır (http://www.blippar.com).

Müzelerde bir sergileme yöntemi olarak kullanılan artırılmış gerçeklik uygulamaları, kullanılan teknolojilerin kamera ya da görüntü tanımlayıcıları tarafından gerçek ortam üzerine aktarılan üç boyutlu nesneler, metin veya resim gibi sanal bilgilerle, ziyaretçilerin eserleri gerçek ortamda varmış gibi algılamalarını sağlamaktadır (Styliani ve diğerleri 2009, 523). Artırılmış gerçeklik uygulamaları, müzelerde sergilenen eserlerin ziyaretçiler tarafından çeşitli açılardan incelenmesine veya karşılaştırılmasına imkân tanımaktadır. Bu da ziyaretçilerin eserlerle çeşitli şekillerde etkileşimde bulunmasını sağladığı gibi müze sergisinin ziyaretçi üzerindeki etkisini arttırmaktadır (Wojciechowski ve diğerleri 2004, 135). Müzelerde kullanılan artırılmış gerçeklik uygulamalarına örnek olarak CHESS (Sosyo-Kişisel Etkileşimler ve Hikaye Anlatımı Yoluyla Kültürel Miras Deneyimleri) projesi verilebilir. Bu proje, Avrupa Komisyonu tarafından ortaklaşa finanse edilen, kişiselleştirme, dijital hikâye anlatımı, etkileşim metodolojileri, anlatı odaklı mobil ve karma gerçeklikte disiplinler arası araştırmayı, bütünleştirmeyi amaçlamaktadır (http://www.chessexperience.eu). Bu proje kapsamında Yunanistan'ın Atina şehrinde bulunan Akropolis Müzesi’nde sergilenen heykellerin eksik kısımları ve kaybolan renkleri gerçek zamanlı olarak tamamlanmaktadır. Böylece ziyaretçilere heykellerin orijinal hallerini incelemeleri sağlanmaktadır (Ioannidis ve diğerleri 2014).

Artırılmış gerçeklik uygulamaları, ziyaretçilerin kültürel miras alanlarındaki tarihi yapıların eski ve orijinal hallerinin zihinlerinde canlandırabilmelerini sağlayarak; beklentilerini karşılayacak bir öğrenme deneyimi yaşatmaktadır (Harmankaya 2010, 14). Kültürel miras alanlarında kullanılan uygulamalara örnek olarak, arkeolojik alanlarda kişiselleştirilmiş artırılmış gerçeklik deneyimini sağlamayı amaçlayan “ARCHEOGUIDE” projesi verilebilir. Bu proje, arkeolojik yapıların yeniden inşa edilmesi ve antik dönemdeki yaşamın ziyaretçilere sanal bilgilerle anlatılmasını mobil veriler, kullanıcı takip sistemleri, üç boyutlu görselleştirmeler ve artırılmış gerçeklik tekniklerini kullanarak 
amaçlamaktadır. Bu proje içerisinde, Yunanistan'ın Olympia Antik Kenti’nde yer alan Hera Tapınağının günümüzdeki görüntüsü üzerine; kullanıcının bakış açısından, artırılmış gerçeklik teknolojisi aracılığıyla, gerçek dünya ortamının üzerine eklenen sanal tapınak görüntüsü sağlanmaktadır. Bu görüntü, kullanıcıların taktığı artırılmış gerçeklik gözlüğüyle sağlanmaktadır. Bu proje kapsamında araştırmaya konu olan kullanıcılar, artırılmış gerçeklik uygulamasının arkeolojik alanın geçmişini daha iyi anlamalarına yardımcı olduğunu ve ziyaretleri sırasında daha iyi bir zaman yönetimi için kişiselleştirme özelliklerinden memnun kaldıklarını belirtmişlerdir (Vlahakis ve diğerleri 2002).

\subsection{Ilgili Araştırmalar}

Alanyazında yer alan turist rehberliği ve teknoloji konularıyla ilgili araştırmalara bakıldığında; Köroğlu (2011), müze ve ören yerlerinde profesyonel turist rehberlerinin yerine elektronik rehberlik uygulamalarının kullanılmasının değerlendirilmesine yönelik yapmış olduğu araştırmada, elektronik rehberlere yönelik bir SWOT analizi gerçekleştirmiştir. Elektronik rehberlerin kesin olarak doğru bilgi sağlaması, istenilen dilde açıklanma yapabilmesi gibi güçlü yönlerinin; tekdüze bir anlatıma sahip olması, cihaza soru sorulamaması gibi zayıf yönlerinin; kültürel miras ve bilgi aktarımını kolaylaştırması, müzenin ziyaretçiler için daha çekici hale gelmesi gibi firsatlarının; turizm olayının sosyal niteliğine zarar vermesi, kültürlerarası etkileşimin sınırlı düzeyde kalması gibi tehditlerinin bulunduğuna değinilmektedir. Araştırmanın sonucunda, turistlerin ve yerel halkın kültürleri arasındaki boşluğu dolduran profesyonel turist rehberlerinin yerine, kültürlerarası etkileşimden uzaklaştırma gibi tehditleri bulunan elektronik rehberlik sistemlerinin kullanımının sınırlandırılması ve bazı tedbirlerin alınmasının turizm sektörü için fayda sağlayacağı belirtilmiştir. Turist rehberleri ile mobil rehberlerin kültürel mirasın aktarılmasındaki yetkinliğinin karşılaştırılması amacıyla Tekin ve diğerleri (2015) yapmış oldukları araştırmanın sonucunda profesyonel turist rehberlerinin kültürel mirasın aktarımında mobil rehberlerden daha etkili olduğu ancak seyahatin kararında ve biçimlendirilmesinde mobil rehberlerin seyahat öncesinde daha etkili bir rol oynadığı belirtilmektedir. Çakmak ve Demirkol (2017), teknolojik gelişmelerin turist rehberliği mesleği üzerine olan etkilerinin belirlenmesi amacıyla yapmış oldukları araştırmada bir SWOT analizinde bulunmuşlardır. Bu analiz sonucunda turist rehberleri teknolojinin, GPS teknolojisi ile yön bulma konusunda yaşanan sorunların giderilmesi, rehberlerin faydalandığı kaynakların fazla yer kaplamaması nedeniyle turistlerin karşısına daha donanımlı çıkabilmeleri gibi güçlü yönlerinin; bilgi teknolojisinin yoğunluğunun bilgi kirliliğine sebep olması, turistlerin veya rehberlerin teknolojiye tam olarak hakim olamaması gibi zayıf yönlerinin; rehberlerin eskiye nazaran coğrafi ve kültürel açıdan kısa sürede daha bilgili hale gelebilmesi, gidilmemiş bölgelere ilişkin rehberlerin teknoloji sayesinde daha kısa sürede hazırlanması gibi firsatlarının ve teknolojik altyapılı rehberlik uygulamalarının turist rehberlerinin yerine geçebilme riski, rehberlerin teknolojiye entegre olamaması nedeniyle rekabette geri kalabilmeleri gibi tehditlerinin olduğuna değinmişlerdir. Tekin ve diğerleri (2017), turist rehberliği mesleğinde yeni teknolojilerin kullanımına yönelik yapmış oldukları araştırmada, bu teknolojilerin, etkili tanıtım yapılmasına fırsat verebilmesi nedeniyle turist rehberlerinin hizmet kalitesini arttıracağına ve tarihi olayların veya kalıntıların interaktif sistemler aracılığıyla anlatılmasının bilginin daha kalıcı olmasını sağlayacağına değinilmektedir. Bununla birlikte, bu teknolojik yeniliklerin turist rehberlerine birer alternatif olarak değil, turist rehberlerinin anlatım araçları olarak değerlendirilmesinin gerekliliği üzerinde durulmuştur.

Artırılmış gerçeklik uygulamaları ile ilgili müzeler, kültürel miras alanları ve turizm üzerine yapılan araştırmalar incelendiğinde; Vlahakis ve diğerleri (2002), kültürel miras alanlarında rekreasyon, eğitim ve bilimsel amaçlı kullanılmak üzere "Archeoguide” uygulamasını geliştirmişlerdir. Yunanistan'ın Olympia Antik Kenti'nde normal kullanıcılar, saha personeli, arkeologlar ve teknoloji uzmanları üzerinde test edilen bu uygulamada, bilgisayar ortamında yaratılan sanal animasyonların artırılmış gerçeklik teknolojisiyle fiziksel dünya görüntüsü üzerine aktarılmasının, bu arkeolojik alanın geçmişinin daha iyi anlaşılmasını sağladığı, kişiselleştirme özelliklerinin ziyaretçiler adına daha iyi bir zaman yönetimi için faydalı olduğu ve uygulamanın navigasyon, sesli anlatım gibi özelliklerinden memnun kalındığ 1 sonucuna ulaşılmıştır. Yoon ve diğerleri (2012), örgün öğretim dışında öğrenme ortamında olmak üzere, bilim müzelerinde artırılmış gerçeklik uygulamalarının ve bilgi yapı iskelelerinin kullanılarak öğrenmeyi geliştirme amacıyla, öğrenciler üzerinde yarı deneysel bir çalışma yapmışlardır. Araştırmanın sonuçlarına göre, öğrencilerin artırılmış gerçeklik ve yapı iskelelerini kullanarak daha büyük derecede bilişsel kazançlar sağladığına değinilmektedir. Özgüneş ve Bozok (2017), artırılmış gerçeklik teknolojilerinin, özellikle yabancı yazında üzerinde durulan önemli noktalarını ele alarak, ilerleyen yıllarda turizm sektörünü ne derecede etkileyebileceği üzerine bir çalışma yapmışlardır. Araştırmanın sonuçları içerisinde, Artırılmış gerçeklik uygulamalarının, kültürel miras alanları ve temalı parklar üzerine yapılmış olan çalışmalar göz önünde bulundurulduğunda, ziyaretçilerin memnuniyet düzeylerini olumlu yönde arttırdığı ve bir turist rehberine ihtiyaç duymadan istedikleri yerleri bağımsız bir şekilde gezebilmelerine olanak tanıdığı belirtilmektedir. Bununla birlikte bu tür teknolojilerin, başta turist rehberliğgi, garsonluk gibi meslekleri olumsuz yönde etkileyeceği araştırmanın diğer sonuçları arasındadir.

\section{Yöntem}

$\mathrm{Bu}$ çalışma, turist rehberlerinin artırılmış gerçeklik uygulamalarına yönelik algılarının belirlenmesini amaçlamaktadır. Çalışmada nitel araştırma yöntemi kullanılmıştır. Nitel araştırmalar, farklı bilgi modüllerinden yola çıkarak bütünü veya kuramı kendisi oluşturması için birincil veya ikincil verilerin toplanmasına aracılık eden bir araştırma türüdür (Kozak 2015, 29). Nitel araştırmacılar, araştırmanın konusu olan fenomenleri, kendi doğal ortamlarında ele almaktadırlar. Dolayısıyla her bir fenomen, araştırmacıların ona yüklemiş olduğu anlamlar çerçevesinde yorumlanmaktadır (Coşkun ve 
diğerleri 2015, 303). Araştırmanın yöntemini nitel araştırma kapsamında yer alan fenomenolojik desen oluşturmaktadır. Fenomenoloji, bireylerin olayları veya durumları nasıl algıladıklarını anlamaya çalışmaktadır (Bal 2016, 26). Fenomenoloji deseni, insanların farkında olduğu fakat ayrıntılı ve derinlemesine bir anlayışa sahip olunamayan deneyimler, kavramlar veya algılar gibi olgulara odaklanmaktadır (Yıldırım ve Şimşek 2016, 69). Fenomenolojik araştırma kapsamında araştırmacılar, öncelikle insanların tecrübe ettikleri ya da edebilecekleri obje veya kavramlar gibi bir fenomen belirleyerek, bu fenomeni tecrübe eden bireyleri tespit etmektedir. Sonraki aşamada, tespit edilen bu bireylerin, belirlenen fenomenle ilgili tecrübelerine yönelik veriler toplanmakta ve analiz edilmektedir. (Güler ve diğerleri 2015, 236). Fenomenolojik araştırmalarda verilerin analizi, yaşantıların ve anlamların ortaya konulmasını amaçlamaktadır. Araştırmanın sonuçları, betimsel bir anlatım ile açıklanarak sık sık doğrudan alıntılara yer verilmektedir (Yıldırım ve Şimşek 2016, 72).

Turist Rehberleri Birliği’nin (TUREB) 2018 yılı içerisinde resmî web sitesinde eş zamanlı olarak verisi sağlanan rehber istatistiklerine göre, Türkiye'de toplamda 10557 kişi olmak üzere ruhsatname sahibi turist rehberi bulunmaktadır. Çalışma kartına sahip eylemli turist rehberi sayısı 7405 kişidir (http://www.tureb.org.tr). Bu doğrultuda bu araştırmanın evrenini, mesleğini eylemli bir şekilde gerçekleştiren çalışma kartlarına sahip 7405 turist rehberi oluşturmaktadır. Bu çalışmada, birçok durumda, olguların ve olayların keşfedilmesi ve açıklanmasında faydalı olan amaçlı örnekleme yöntemlerinden ölçüt örnekleme metodu seçilmiştir. Ölçüt örnekleme yönteminin temeli, daha önce belirlenmiş bir dizi ölçütü karşılamakta olan bütün durumların çalışılmasına dayanmaktadır. Bu örnekleme yönteminde söz konusu ölçüt veya ölçütler araştırmacı tarafından oluşturulabilmekte ve daha önceden hazırlanmış bir ölçüt listesi kullanılabilmektedir (Yıldırım ve Şimşek 2016, 118-122).

Diğer nitel araştırma yöntemlerinde olduğu gibi fenomenolojik araştırmalarda da, örneklemin rastgele yöntemler ile birlikte değil de amaca yönelik örnekleme yöntemiyle yapılması ve örnekleme konu olan katılımcı sayısının çok az olması nedeniyle, araştırma sonuçlarının bütün evrene genellenememesi, bu araştırma yönteminin en önemli sınırlılığı olarak gösterilmektedir. Ancak tüm bu sınırlılıklara rağmen, fenomenolojik araştırmalar insan davranışları hakkında çok önemli bilgiler verme yeteneğine sahip olmaktadır (Güler ve diğerleri 2015, 254). Bu doğrultuda, bu araştırmanın çalışma grubunu, Türkiye'nin çeşitli bölgelerinde eylemli olarak turist rehberliği mesleğini icra eden, Kültür ve Turizm Bakanlığı'ndan onaylı çalışma kartlarına sahip toplamda 100 profesyonel turist rehberi oluşturmaktadır. Ancak araştırma kapsamında artırılmış gerçeklik uygulamaları ile ilgili bilgi sahibi olan turist rehberi sayısının 22 olması nedeniyle, söz konusu rehberlerin yorumları araştırma içerisinde değerlendirmeye alınabilmiştir. Turist rehberlerine artırılmış gerçeklik uygulamaları hakkında yöneltilen sorulara verdikleri cevapların benzeşmesi ve özellikle müze ile ören yerlerinde bu uygulamaların kullanımının kısıtlılığı nedeniyle, araştırmanın çalışma grubu 100 kişi ile sınırlı tutulmuştur.

Araştırmanın verileri, görüşme yöntemi türlerinden olan yarı yapılandırılmış görüşme tekniğiyle elde edilmiştir. Bu doğrultuda, yarı yapılandırılmış görüşme formu oluşturulmuş ve bu form aracılığıyla araştırmanın verileri sağlanmıştır. Yarı yapılandırılmış anket formunun içerisinde yer alan sorular artırılmış gerçeklik uygulamaları ile ilgili literatür taraması sonucunda oluşturulmuştur (Azuma ve diğerleri 2001; Vlahakis ve diğerleri 2002; Höllerer ve Feiner 2004; Bimber ve Raskar 2005; Styliani ve diğerleri 2009; Van Krevelen ve Poelman 2010; Carmigniani ve Furth 2011; Yoon ve diğerleri, 2012; Kipper ve Rampolla 2013; Billinghurst ve diğerleri 2014; Han ve diğerleri 2014). Turist rehberlerinin artırılmış gerçeklik uygulamalarıyla ilgili algılarının belirlenmesi amacıyla oluşturulan kapalı uçlu, çoktan seçmeli ve açık uçlu soruların yer aldığı yarı yapılandırılmış görüşme formuna verdikleri cevaplar, birebir yapılan görüşmeler sonucunda görüşme formuna işaretlenmiş ve not edilmiştir. Veri toplama sürecinde görüşme formuna bağlı kalınmış; toplanan sosyo-demografik ve mesleki özelliklerin analiz edilmesi amacıyla SPSS Paket 21 programı aracılığıly veri seti oluşturulmuştur. Araştırmanın verileri, Kültür ve Turizm Bakanlığı'ndan onaylı çalışma kartlarına sahip olan toplamda 100 turist rehberi üzerinden, 2018 yılı Haziran ve Ağustos ayları içerisinde İstanbul ili ve çevresinden sağlanmıştır.

Turist rehberlerinin, artırılmış gerçeklik ile ilgili görüşme formunda yer alan açık uçlu sorulara vermiş olduğu yanıtların değerlendirilmesinde betimsel analiz yöntemi kullanılmıştır. Araştırmaya dahil edilen 100 turist rehberinden 22 kişinin, artırılmış gerçeklik uygulamaları hakkında bilgi sahibi olması nedeniyle, yalnızca söz konusu turist rehberlerinin yorumları analize tabi tutulmuştur. Bu türdeki analizin amacı, elde edilen bulguların düzenlenmiş ve yorumlanmış bir şekilde okuyuculara sunulmasıdır. Bu amaç doğrultusunda elde edilen veriler, sistematik ve açık bir şekilde betimlenmektedir. Bu betimlemelerin açıklanması, yorumlanması ve neden sonuç ilişkilerinin irdelenmesiyle birlikte birtakım sonuçlara ulaşılmaktadır. Ortaya çıkarılmış olan temaların anlamlandırılması, ilişkilendirilmesi ve ileriye yönelik tahminlerde bulunulması, araştırmacının belirteceği yorumlamaların kapsamı arasında yer alabilmektedir. Betimsel analiz yöntemi dört aşamadan oluşmaktadır (Yıldırım ve Şimşek 2016, 239-241): betimsel analiz için bir çerçeve oluşturulması; tematik çerçeveye göre verilerin işlenmesi; bulguların tanımlanması ve bulguların yorumlanması.

Araştırmanın geçerliğinin sağlanması amacıyla toplanan veriler ayrıntılı bir biçimde rapor edilmiş ve araştırmanın sonuçlarına nasıl ulaşıldığı açıklanmıştır (Yıldırım ve Şimşek 2016, 270). Araştırmaya dahil edilen 100 turist rehberi içerisinden artırılmış gerçeklik uygulamalarıyla ilgili bilgiye sahip olan 22 katılımcının yorumları, tematik çerçeve kapsamına alınmadan, doğrudan alıntı yöntemiyle birlikte açıklanmış ve yorumlanarak değerlendirilmiştir. Araştırmanın güvenirliğinin sağlanması amacıyla da araştırmacı tarafından yapılmış olan değerlendirmeler, konuyla ilgili bir uzmanın görüşlerine başvurularak yapılmıştır. Doğrudan alıntılar, katılımcıların K1 ve K22 aralığında kodlandırılmasıyla birlikte metin içerisinde belirtilmiştir. Turist rehberlerinin artırılmış gerçeklik uygulamalarına olan algılarına yönelik yapmış oldukları tanımlamalar ve açıklamaların benzerliği ve de bu uygulamanın kullanımına yönelik deneyimlerin az sayıda olması nedeniyle, rehberlerin yapmış olduğu yorumlar tematik çerçeve kapsamına alınamamıştır. 


\section{Bulgular ve Yorumlar}

\subsection{Katılımcıların Sosyo-Demografik ve Mesleğine İlişkin Özellikleri}

Tablo 1'de araştırmaya katılan turist rehberlerinin sosyo-demografik özelliklerine ilişkin bulgular yer almaktadır. Turist rehberlerinin cinsiyet dağılımı incelendiğinde \%50'sinin kadın $(n=50)$ ve \%50'sinin erkek $(n=50)$ katılımcılardan oluştuğu görülmektedir. Katılımcıların \%3'ünün 18-25 $(\mathrm{n}=3)$ yaş aralığında, \%37'sinin 26-35 (n=37) yaş aralığında, \%36'sının 36-45 (n=36) yaş aralığında, \%17'sinin 46-55 (n=17) yaş aralığında, \% 4'ünün 56-65 (n=4) yaş aralığında ve \% 3'ünün ise 66 ve üzeri $(n=3)$ yaşlarında oldukları gözlemlenmektedir. Medeni hal değişkenine bakıldığında, katılımcıların \%63'ünün evli $(n=63)$ ve \%37'sinin de bekar $(n=37)$ olduğu tespit edilmiştir. Katılımcıların öğrenim durumlarının büyük çoğunluğunu \%49 oranında lisans $(n=49)$ ve $\% 41$ oranında lisansüstü $(n=41)$ mezunu oluşturmakla birlikte \%7'sinin ön lisans $(n=7)$ ve \%3'ünün lise $(n=3)$ mezunu olduğu görülmektedir.

Araştırmaya katılan turist rehberlerinin mesleğine ilişkin özellikleri incelendiğinde; turist rehberlerinin büyük bir bölümünün meslek eğitimlerini \%52'lik oranla bakanlık kursundan $(n=52)$ aldıkları görülmekle birlikte, \%28'inin meslek yüksek okulu $(\mathrm{n}=28)$ ve \%20'sinin de lisans $(\mathrm{n}=20)$ derecesinden almış oldukları gözlemlenmektedir. Turist rehberlerinin \%18'inin 1-5 yıllık (n=18); \%24'ünün 6-10 y1llı ( $\mathrm{n}=24)$; \%23'ünün 11-15 y1llık (n=23) ve \%35'inin 16 y1l ve üzerinde $(n=35)$ meslek tecrübesine sahip oldukları görülmektedir. Katılımcıların \%81'i serbest ve \%19'u acentaya bağlı olarak çalıştıklarını belirtmişlerdir. Araştırmaya dahil olan turist rehberlerinin en yoğun olarak çalıştıkları bölgeleri, sırasıyla Marmara Bölgesi (\%31), Ege Bölgesi (\%29), Akdeniz Bölgesi (\%21), Karadeniz Bölgesi (\%11) ve İç Anadolu Bölgesi $(\% 8)$ oluşturmaktadır. Turist rehberlerinin çalıştıkları tur çeşitlerinin de $\% 52$ 'lik oranla günübirlik turlar $(n=52)$, \%43 oranında Anadolu turları $(n=43)$ ve $\% 5$ oranında yurtdışı turlar $(n=5)$ olduğu gözlemlenmektedir. Buna ek olarak, katılımcılardan 82 kişinin İngilizce, 26 kişinin Almanca, 34 kişinin Rusça, 4 kişinin Portekizce, 3 kişinin Fransızca, 3 kişinin Japonca, 2 kişinin İtalyanca ve 1 kişinin de Arapça dillerinde hizmetlerini gerçekleştirmekte olduklarını belirtmişlerdir.

Tablo 1. Katılımcıların Sosyo-Demografik Özellikleri

\begin{tabular}{|c|c|c|}
\hline & $n$ & $\%$ \\
\hline \multicolumn{3}{|l|}{ Cinsiyet } \\
\hline Kadın & 50 & 50,0 \\
\hline Erkek & 50 & 50,0 \\
\hline Toplam & 100 & 100 \\
\hline \multicolumn{3}{|l|}{ Yaş } \\
\hline $18-25$ & 3 & 3,0 \\
\hline $26-35$ & 37 & 37,0 \\
\hline $36-45$ & 36 & 36,0 \\
\hline $46-55$ & 17 & 17,0 \\
\hline $56-65$ & 4 & 4,0 \\
\hline 66 ve üzeri & 3 & 3,0 \\
\hline Toplam & 100 & 100 \\
\hline \multicolumn{3}{|c|}{ Medeni Durum } \\
\hline Evli & 63 & 63,0 \\
\hline Bekar & 37 & 37,0 \\
\hline Toplam & 100 & 100 \\
\hline \multicolumn{3}{|c|}{ Öğrenim Durumu } \\
\hline Lise & 3 & 3,0 \\
\hline Ön Lisans & 7 & 7,0 \\
\hline Lisans & 49 & 49,0 \\
\hline Lisansüstü & 41 & 41,0 \\
\hline Toplam & 100 & 100 \\
\hline
\end{tabular}

\subsection{Katılımcıların Artırılmış Gerçeklik Uygulamalarına Yönelik Algılamalarının Değerlendirilmesi}

Araştırmaya dahil edilen turist rehberlerine, artırılmış gerçeklik uygulamaları ile ilgili bilgi sahibi olup olmadıklarına yönelik iletilen soruda, katılımcılardan yalnızca 22 kişi bu uygulamalar hakkında bilgi sahibi olduğunu belirtmişlerdir. Diğer 78 turist rehberinin ise bu uygulamalar hakkında bilgi sahibi olmadıkları görülmektedir (Tablo 2). Dolayısıyla, bu uygulamalar hakkında bilgi sahibi olmayan turist rehberlerinin görüşlerine danışılamamıştır. Bu doğrultuda, artırılmış gerçeklik uygulamaları hakkında bilgi sahibi olan 22 turist rehberinin sağlamış olduğu veriler araştırma içerisinde değerlendirmeye tabi tutulmuştur. 
Tablo 2. Artırılmış Gerçeklik Uygulamalarının Turist Rehberleri Tarafından Bilinirliği

\begin{tabular}{|l|c|c|}
\hline Artırılmış Gerçeklik Uygulamaları Hakkinda Bilginiz Var mı? & $n$ & $\%$ \\
\hline Evet & 22 & 22,0 \\
\hline Hayır & 78 & 78,0 \\
\hline Toplam & 100 & 100 \\
\hline
\end{tabular}

Artırılmış gerçeklik uygulamaları ile ilgili bilgi sahibi olan 22 turist rehberinin demografik özelliklerine yönelik yapılan frekans analizi sonucunda, 10 kişinin kadın $(\% 45,5)$ ve 12 kişinin erkek $(\% 54,5)$ katılımcılardan oluştuğu görülmektedir. Bu uygulamaları kullanan turist rehberlerinin yaş aralığına bakıldığında, 11 kişinin 26-35 yaş (\%50,0), 5 kişinin 36-45 yaş $(\% 22,7)$ ve 6 kişinin ise $46-55$ yaş $(\% 27,3)$ aralığında olduğu gözlemlenmektedir. Medeni hal durumlarında 11 kişinin evli, 11 kişinin ise bekar olduğu görülmektedir. Katılımcılardan 11 kişinin lisans (\%50,0), 10 kişinin lisansüstü $(\% 45,5)$ ve 1 kişinin de ön lisans $(\% 4,5)$ düzeyinde öğrenim durumuna sahip olduğu gözlemlenmektedir. Artırılmış gerçeklik uygulamaları hakkında bilgi sahibi olan 22 turist rehberinin mesleğine ilişkin özelliklerine bakıldığında, meslek eğitimlerini 9 kişi olmak üzere bakanlık kursundan $(\% 40,9), 7$ kişi olmak üzere turizm rehberliği lisans bölümünden $(\% 31,8)$ ve 6 kişi olmak üzere de turizm rehberliği ön lisans bölümünden $(\% 27,3)$ almış oldukları tespit edilmiştir. Katılımcılar içerisinde 20 kişinin İngilizce, 4 kişinin Almanca, 4 kişinin Rusça ve 1 kişinin Arapça dillerinde mesleğini icra etmekte olduğu görülmektedir. Katılımcılardan 5 kişinin 1-5 yıl (\%22,7), 3 kişinin 6-10 y1l $(\% 13,6), 6$ kişinin 11-15 yıl $(\% 27,3)$ ve 8 kişinin de 16 yıl ve üzeri yıl aralığında meslek tecrübesine sahip olduğu gözlemlenmektedir. Katılımcılarından 19 kişi serbest $(\% 86,4), 3$ kişi de acentaya bağlı $(\% 13,6)$ olarak çalıştıklarını belirtmişlerdir. Turist rehberlerinin mesleklerini başta 7 kişi Marmara Bölgesi $(\% 31,8)$ ve 7 kişi Ege Bölgesi $(\% 31,8)$ olmak üzere, 4 kişinin Karadeniz Bölgesi (\%18,2), 2 kişinin Akdeniz Bölgesi $(\% 9,1)$ ve 2 kişinin de İç Anadolu Bölgesi'nde $(\% 9,1)$ gerçekleştirdikleri görülmektedir. 13 katılımcı mesleklerini günübirlik turlarda $(\% 59,1)$ yerine getirirken, 7 kişi Anadolu turları $(\% 31,8)$ ve 2 kişi de yurtdışı turlarda $(\% 9,1)$ mesleklerini icra etmektedir.

Turist rehberlerine artırılmış gerçeklik uygulamaları ile ilgili bilgiyi nereden aldıklarına yönelik belirtilen soruda; 9 katılımcı bu uygulamaları yazılı ve görsel medya $(\% 40,9)$ yoluyla aldığını, 5 katılımcı sosyal medya $(\% 22,7)$ vasıtasılya aldığını, 5 katılımcı diğer turist rehberlerinden $(\% 22,7)$ aldığını ve 3 katılımcı turistler $(\% 13,7)$ aracılığıyla aldıklarını belirtmişlerdir (Tablo 3).

Tablo 3. “Artırılmış Gerçeklik Uygulamaları İle İlgili Bilgiyi Nereden Aldınız?” Sorusuna Yönelik Yanıtlar

\begin{tabular}{|l|l|c|c|}
\hline Soru & Kodlar & $n$ & $\%$ \\
\hline \multirow{4}{*}{ Artırılmıs Gerçeklik Uygulamaları İle İlgili Bilgiyi Nereden Aldınız? } & Yazılı ve görsel medya & 9 & 40,9 \\
\cline { 2 - 4 } & Sosyal medya & 5 & 22,7 \\
\cline { 2 - 4 } & Diğer turist rehberleri & 5 & 22,7 \\
\cline { 2 - 4 } & Turistler & 3 & 13,7 \\
\cline { 2 - 5 } & Toplam & 22 & 100 \\
\hline
\end{tabular}

Turist rehberlerine yöneltilen “Artırılmış gerçeklik uygulamalarını nasıl tanımlarsınız?” sorusuyla ilgili verdikleri yanıtlar ele alındığında; katılımcıların \%40,90'ının (K1, K3, K4, K8, K10, K11, K15, K20, K21) yaptıkları tanımlar, bu uygulamaların "bilgi sağlamayı destekleyen teknolojiler" olduğu üzerinedir. Turist rehberlerinin artırılmış gerçeklik uygulamaları hakkında \%36,36'sının (K2, K3, K5, K9, K12, K18, K19, K22) yapmış oldukları tanımların, “sanal ve gerçek görüntüleri birleştiren teknolojiler" çerçevesi kapsamında olduğu görülmektedir. K7, K13 ve K14 kodlu katılımcılar $(\% 13,63)$ bu uygulamaları "sanal gerçeklik" olarak tanımlamışlardır. K4 ve K6 kodlu katılımcılar $(\% 9,09)$ bu uygulamaların "turlarda ve diğer alanlarda fayda sağlayacak bir teknoloji” olduğuna değinmektedirler. K8 ve K10 kodlu katılımcılar $(\% 9,09)$ ise "artırılmış gerçeklik uygulamalarının sağladığı bilgilere sanal ortamdan ulaşıldı ̆̆ına" işaret etmektedir. K16 kodlu turist rehberi $(\% 4,54)$ artırılmış gerçekliğin “teknolojik bir uygulama” olduğuna değinmekle birlikte; K17 kodlu turist rehberi $(\% 4,54)$ "gerçeğe yakın bir teknoloji” olarak tanımlamıştır (Tablo 4). 
Tablo 4. “Artırılmış gerçeklik uygulamalarını nasıl tanımlarsınız?” Sorusuna Yönelik Yanıtlar

\begin{tabular}{|c|c|c|c|c|}
\hline Soru & Kodlar & Katılımclar & $n$ & $\%$ \\
\hline \multirow{7}{*}{$\begin{array}{l}\text { Artırılmış gerçeklik } \\
\text { uygulamalarını nasıl } \\
\text { tanımlarsınız? }\end{array}$} & Bilgi sağlamayı destekleyen teknolojilerdir & $\begin{array}{l}\mathrm{K} 1, \mathrm{~K} 3 *, \mathrm{~K} 4 *, \mathrm{~K} 8 *, \mathrm{~K} 10^{*}, \mathrm{~K} 11, \mathrm{~K} 15 \\
\mathrm{~K} 20, \mathrm{~K} 21\end{array}$ & 9 & 40,90 \\
\hline & Sanal ve gerçek görüntüleri birleştiren teknolojilerdir & K2, K3*, K5, K9, K12, K18, K19, K22 & 8 & 36,36 \\
\hline & Sanal gerçekliktir & $\mathrm{K} 7, \mathrm{~K} 13, \mathrm{~K} 14$ & 3 & 13,63 \\
\hline & Turlarda ve diğer alanlarda fayda sağlayacak bir teknolojidir & K4*, K6 & 2 & 9,09 \\
\hline & $\begin{array}{l}\text { Artırılmış gerçeklik uygulamalarının sağladığı bilgilere sanal } \\
\text { ortamdan ulaşılmaktadır }\end{array}$ & $\mathrm{K} 8 *, \mathrm{~K} 10^{*}$ & 2 & 9,09 \\
\hline & Teknolojik bir uygulamadır & K16 & 1 & 4,54 \\
\hline & Gerçeğe yakın bir teknolojidir & K17 & 1 & 4,54 \\
\hline \multicolumn{3}{|l|}{ Toplam } & 22 & 100 \\
\hline
\end{tabular}

Turist rehberlerinin \%22,7'si (K1, K8, K18, K19, K20) olmak üzere toplamda 5 kişinin bu uygulamaları daha önce kullandığı, diğer 17 katılımcının $(\% 77,3)$ ise bu uygulamaları daha önce deneyimlemediği tespit edilmiştir (Tablo 5).

Tablo 5. "Bu uygulamaları daha önce kullandınız mı?” Sorusuna Yönelik Yanıtlar

\begin{tabular}{|l|l|c|c|}
\hline Bu uygulamaları daha önce kullandinız mı? & Katllimcllar & $n$ & $\%$ \\
\hline Evet & $\mathrm{K} 1, \mathrm{~K} 8, \mathrm{~K} 18, \mathrm{~K} 19, \mathrm{~K} 20$ & 5 & 22,7 \\
\hline Hayır & $\mathrm{K} 2, \mathrm{~K} 3, \mathrm{~K} 4, \mathrm{~K} 5, \mathrm{~K} 6, \mathrm{~K} 7, \mathrm{~K} 9, \mathrm{~K} 10, \mathrm{~K} 11, \mathrm{~K} 12, \mathrm{~K} 13, \mathrm{~K} 14, \mathrm{~K} 15, \mathrm{~K} 16, \mathrm{~K} 17, \mathrm{~K} 21$, & 17 & 77,3 \\
& $\mathrm{~K} 22$ & 22 & 100 \\
\hline Toplam & & 2 & \\
\hline
\end{tabular}

Artırılmış gerçeklik uygulamalarını daha önce kullanan 5 turist rehberinden K1, K8, K19 ve K20 kodlu toplamda 4 katılımcı $(\% 18,18)$ bu uygulamaları turlarında materyal olarak kullandığını, diğer K18 kodlu katılımc1 (\%4,54) ise teknolojiye ilgi duymasından dolayı kullandığını belirtmiştir (Tablo 6).

Tablo 6. “Artırılmış Gerçeklik Uygulamalarını Hangi Amaçla Kullandınız?” Sorusuna Yönelik Yanıtlar

\begin{tabular}{|c|c|c|c|c|}
\hline Soru & Kodlar & Katılımcılar & $n$ & $\%$ \\
\hline \multirow{3}{*}{$\begin{array}{l}\text { Artırılmış Gerçeklik } \\
\text { Uygulamalarını } \\
\text { Hangi Amaçla } \\
\text { Kullandınız? }\end{array}$} & Turlarımda materyal olarak & K1, K8, K19, K20 & 4 & 18,18 \\
\hline & Teknolojiye ilgi duymamdan dolayı & K18 & 1 & 4,54 \\
\hline & Kullanılmamış & $\begin{array}{l}\text { K2, K3, K4, K5, K6, K7, K9, K10, K11, K12, K13, K14, K15, } \\
\text { K16, K17, K21, K22 }\end{array}$ & 17 & 77,27 \\
\hline \multicolumn{3}{|l|}{ Toplam } & 22 & 100 \\
\hline
\end{tabular}

K1, K8, K19 ve K20 kodlu 4 katılımcının $(\% 18,18)$ artırılmış gerçeklik uygulamalarına internet üzerinden, diğer K18 $(\% 4,54)$ kodlu katılımcının ise bu uygulamalara deneme standları aracılığıyla ulaştığı görülmektedir (Tablo 7).

Tablo 7. “Artırılmış Gerçeklik Uygulamalarına Nasıl Ulaştınız?” Sorusuna Yönelik Yanıtlar

\begin{tabular}{|c|c|c|c|c|}
\hline Soru & Kodlar & Katılımcılar & $n$ & $\%$ \\
\hline \multirow{3}{*}{$\begin{array}{l}\text { Artırılmış Gerçeklik Uygulamalarına } \\
\text { Nasıl Ulaştınız? }\end{array}$} & İnternet üzerinden & $\mathrm{K} 1, \mathrm{~K} 8, \mathrm{~K} 19, \mathrm{~K} 20$ & 4 & 18,18 \\
\hline & Deneme standları üzerinden & K18 & 1 & 4,54 \\
\hline & Kullanılmamış & $\begin{array}{l}\text { K2, K3, K4, K5, K6, K7, K9, K10, K11, K12, K13, } \\
\text { K14, K15, K16, K17, K21, K22 }\end{array}$ & 17 & 77,27 \\
\hline \multicolumn{3}{|l|}{ Toplam } & 22 & 100 \\
\hline
\end{tabular}


Artırılmış gerçeklik uygulamaları hakkında bilgi sahibi olan 22 turist rehberinden K8 ve K18 kodlu katılımcılar olmak üzere yalnızca 2 kişinin $(\% 9,09)$, daha önce turlarında bu uygulamaları kullanarak anlatımlarını gerçekleştirdiği görülmektedir. Diğer 20 katılımcının $(\% 90,90)$ ise daha önce bu uygulamaları turlarında anlatımlarını gerçekleştirirken kullanmadıkları tespit edilmiştir (Tablo 8).

Tablo 8. “Turlarınızda bu uygulamaları kullanarak anlatımlarınızı gerçekleştirdiniz mi?” Sorusuna Yönelik Yanıtlar

\begin{tabular}{|c|c|c|c|}
\hline Turlarınızda bu uygulamaları kullanarak anlatımlarınızı gerçekleştirdiniz mi? & Katllimclar & $n$ & $\%$ \\
\hline Evet & K8, K18 & 2 & 9,09 \\
\hline Hayır & $\begin{array}{l}\text { K1, K2, K3, K4, K5, K6, K7, K9, K10, K11, K12, } \\
\text { K13, K14, K15, K16, K17, K19, K20, K21, K22 }\end{array}$ & 20 & 90,90 \\
\hline Toplam & & 22 & 100 \\
\hline
\end{tabular}

K8 kodlu katılımcı $(\% 4,54)$ bu uygulamaları ören yerlerinde kullandığını belirtirken, K18 kodlu katılımcı (\%4,54) ise müzelerde kullandığını belirtmiştir. Ancak hangi müze ve ören yerlerinde kullandıkları bilgisine ulaşılamamıştır (Tablo 9).

Tablo 9. “Artırılmış gerçeklik uygulamalarını nerelerde kullandınız?” Sorusuna Yönelik Yanıtlar

\begin{tabular}{|c|c|c|c|c|}
\hline Soru & Kodlar & Katılımcilar & $n$ & $\%$ \\
\hline \multirow{3}{*}{$\begin{array}{l}\text { Artırılmış gerçeklik } \\
\text { uygulamalarını nerelerde } \\
\text { kullandınız? }\end{array}$} & Ören yerlerinde & K8 & 1 & 4,54 \\
\hline & Müzelerde & K18 & 1 & 4,54 \\
\hline & - & $\begin{array}{l}\text { K1, K2, K3, K4, K5, K6, K7, K9, K10, K11, K12, K13, K14, K15, K16, K17, } \\
\text { K19, K20, K21, K22 }\end{array}$ & 20 & 90,9 \\
\hline \multicolumn{3}{|l|}{ Toplam } & 22 & 100 \\
\hline
\end{tabular}

Turist rehberlerinin "Sizce bu tür uygulamaları kullanmak ne derece önemli/ne derece önemsiz?” sorusuna vermiş oldukları cevaplar incelendiğinde; katılımcıların \%45,45'i (K1, K2, K3, K7, K10, K11, K15, K16, K20, K21), bu uygulamaların "gezilen tarihi yerler veya herhangi bir konu hakkında bilgi alınabilmesini ve turist rehberleri tarafindan da bilgi verilebilmesini sağlayan uygulamalar" olduğuna değinmektedirler. Turist rehberlerinin \%22,72'si (K3, K9, K13, $\mathrm{K} 14$, K20), bu uygulamaların "insanların ve turist rehberlerinin işini kolaylaştıran teknolojiler" olduğunu belirtmektedirler. Katılımcılardan $\mathrm{K} 4$, K5, ve K18 kodlu turist rehberleri artırılmış gerçeklik uygulamalarının kullanımının oldulça önemli olduğuna değinmektedirler $(\% 13,62)$. K6 ve K19 kodlu katılımcılar (\%9,09) ise bu uygulamaların, "insanların teknolojiye ilgili olmasından dolayı daha çok faydalı olabilecek ve de anlatılan konulara ilgiyi arttırabilecek bir teknoloji” olduğundan söz etmektedirler. K12 kodlu katılımc1 $(\% 4,54)$, bu uygulamaların özellikle "kalabalık olan müzelerde kullanımının önemli olduğuna" değinmektedir. K17 kodlu turist rehberinin (\%4,54), "antik kentlerin kalıntılarının az olması nedeniyle bu tür uygulamalarının kullanımının önemli olabileceğine" işaret etmektedir. K22 kodlu katılımc1 (\%4,54), bu uygulamaların “sanal ortamdan bilgi alınabilmesini sağladığını” belirtmektedir. Diğer yandan, K8 kodlu turist rehberinin $(\% 4,54)$, “artırılmış gerçeklik uygulamalarının henüz yeterli alt yapısı olmadığından ve bu uygulamaların kullanımının zor olduğundan” söz etmektedir (Tablo 10).

Tablo 10. "Sizce bu tür uygulamaları kullanmak ne derece önemli/ne derece önemsiz?” Sorusuna Yönelik Yanıtlar

\begin{tabular}{|c|c|c|c|c|}
\hline Soru & Kodlar & Katılımcılar & $n$ & $\%$ \\
\hline \multirow{6}{*}{$\begin{array}{l}\text { Sizce bu tür } \\
\text { uygulamaları } \\
\text { kullanmak ne } \\
\text { derece önemli/ne } \\
\text { derece önemsiz? }\end{array}$} & $\begin{array}{l}\text { Gezilen tarihi yerler veya herhangi bir konu hakkında bilgi alınabilmesini } \\
\text { ve turist rehberleri tarafından da bilgi verilebilmesini sağlayan } \\
\text { uygulamalardır }\end{array}$ & $\begin{array}{l}\mathrm{K} 1, \mathrm{~K} 2, \mathrm{~K} 3, \mathrm{~K} 7, \mathrm{~K} 10, \\
\mathrm{~K} 11, \mathrm{~K} 15, \mathrm{~K} 16, \mathrm{~K} 20, \mathrm{~K} 21\end{array}$ & 10 & 45,45 \\
\hline & İnsanların ve turist rehberlerinin işini kolaylaştıran teknolojilerdir & $\mathrm{K} 3, \mathrm{~K} 9, \mathrm{~K} 13, \mathrm{~K} 14, \mathrm{~K} 20$ & 5 & 22,72 \\
\hline & Oldukça önemlidir & K4, K5, K18 & 3 & 13,62 \\
\hline & $\begin{array}{l}\text { İnsanların teknolojiye ilgili olmasından dolayı daha çok faydalı olabilecek } \\
\text { ve de anlatılan konulara ilgiyi arttırabilecek bir teknolojidir }\end{array}$ & K6, K19 & 2 & 9,09 \\
\hline & Kalabalık olan müzelerde kullanımı önemlidir & K12 & 1 & 4,54 \\
\hline & $\begin{array}{l}\text { Antik kentlerin kalıntılarının az olması nedeniyle bu tür uygulamalarının } \\
\text { kullanımı önemlidir }\end{array}$ & K17 & 1 & 4,54 \\
\hline
\end{tabular}




\begin{tabular}{|l|l|l|c|c|}
\hline & Sanal ortamdan bilgi alınabilmesini sağlamaktadır & K22 & 1 & 4,54 \\
\cline { 2 - 5 } & $\begin{array}{l}\text { Artırılmıș gerçeklik uygulamalarının henüz yeterli alt yapısı yoktur ve bu } \\
\text { uygulamaların kullanımı zordur }\end{array}$ & K8 & 4,54 \\
\hline Toplam & & 22 & 100 \\
\hline
\end{tabular}

Artırılmış gerçeklik uygulamalarının turlarda kullanımının yeterli olup olmadığına ilişkin turist rehberlerine yöneltilen soruda, K3 ve K21 kodlu katılımcıların $(\% 9,09)$ çok fazla olmasa da bu uygulamaların kullanımının yeterli olduğunu belirtmektedirler. Diğer 20 turist rehberinin $(\% 90,90)$ ise bu uygulamaların turlarda kullanımının yeterli olmadığına değinmişlerdir (Tablo 11). Bununla birlikte, turist rehberlerine artırılmış gerçeklik uygulamalarını soran veya isteyen misafirlerinin olup olmadığına yönelik iletilen soruda tüm katılımcıların (n=22) "hayır" cevabını verdikleri tespit edilmiştir.

Tablo 11. “Artırılmış gerçeklik uygulamalarının turlarda kullanımı yeterli mi?” Sorusuna Yönelik Yanıtlar

\begin{tabular}{|c|c|c|c|c|}
\hline Soru & Kodlar & Katılımcilar & $n$ & $\%$ \\
\hline \multirow{2}{*}{$\begin{array}{l}\text { Artırılmış gerçeklik } \\
\text { uygulamalarının } \\
\text { turlarda kullanımı } \\
\text { yeterli mi? }\end{array}$} & Evet & $\mathrm{K} 3, \mathrm{~K} 21$ & 2 & 9,09 \\
\hline & Hayır & $\begin{array}{l}\text { K1, K2, K3, K4, K5, K6, K7, K9, K10, K11, K12, K13, K14, K15, K16, K17, K19, } \\
\text { K20, K21, K22 }\end{array}$ & 20 & 90,90 \\
\hline \multicolumn{3}{|l|}{ Toplam } & 22 & 100 \\
\hline
\end{tabular}

Turist rehberlerinin "Sizce bu uygulamaların turist rehberlerine olumlu ve olumsuz olmak üzere ne gibi etkileri olabilir?" sorusuna verdikleri yanıtlara bakıldığında; katılımcıların \%45,45’i (K1, K2, K7, K9, K13, K14, K15, K16, K20, $\mathrm{K} 22$ ), artırılmış gerçeklik uygulamalarının "turist rehberlerinin işini kolaylaştırabilecek faydalı teknolojiler" olduğundan söz etmektedirler. Katılımcılardan K4, K5, K12 ve K19 kodlu turist rehberleri $(\% 18,18)$ artırılmış gerçeklik uygulamalarının yalnızca "olumlu yönde etkileri" olacağına işaret etmektedir. Turist rehberlerinin \% 13,63 'ü (K8, K10, K11), bu uygulamaların "rehberlerin eksik veya uzmanlık alanıyla ilgili verdikleri bilgileri tamamlayacağına" değinmektedirler. K17 ve K18 kodlu turist rehberleri $(\% 9,09)$, artırılmış gerçeklik uygulamalarının "rehberlerin anlatımlarını destekleyerek olumlu bir etki yaratacağına" işaret etmektedirler. K6 kodlu turist rehberi $(\% 4,54)$, bu uygulamaların kullanımının olumlu etkiler bırakacağına değinmekle birlikte, "insanların beklentilerini karşılayabilecek bir uygulama" olacağını belirtmektedir. K21 kodlu turist rehberinin $(\% 4,54)$ ise bu uygulamaların "merak edilen her şey hakkında bilgi sağlayacağından" söz ettiği görülmektedir. Diğer yandan, K3 kodlu turist rehberi $(\% 4,54)$, artırılmış gerçeklik uygulamalarının kullanımının, "merak ve nostalji duygusuna zarar verebileceği; bunun sonucunda da turist rehberlerinin anlatımlarına olumsuz yönde etki edebileceği” ş̧eklinde görüşlerini belirtmiştir (Tablo 12).

Tablo 12. "Sizce bu uygulamaların turist rehberlerine olumlu ve olumsuz olmak üzere ne gibi etkileri olabilir?" Sorusuna Yönelik Yanıtlar

\begin{tabular}{|c|c|c|c|c|}
\hline Soru & Kodlar & Katılımcilar & $n$ & $\%$ \\
\hline \multirow{7}{*}{$\begin{array}{l}\text { Sizce bu } \\
\text { uygulamaların turist } \\
\text { rehberlerine olumlu ve } \\
\text { olumsuz olmak üzere } \\
\text { ne gibi etkileri } \\
\text { olabilir? }\end{array}$} & Turist rehberlerinin işini kolaylaştırabilecek faydalı teknolojilerdir & $\begin{array}{l}\mathrm{K} 1, \mathrm{~K} 2, \mathrm{~K} 7, \mathrm{~K} 9, \mathrm{~K} 13, \mathrm{~K} 14, \\
\mathrm{~K} 15, \mathrm{~K} 16, \mathrm{~K} 20, \mathrm{~K} 22\end{array}$ & 10 & 45,45 \\
\hline & Olumlu yönde etkiler & K4, K5, K12, K19 & 4 & 18,18 \\
\hline & $\begin{array}{l}\text { Rehberlerin eksik veya uzmanlık alanıyla ilgili verdikleri bilgileri } \\
\text { tamamlayacaktır }\end{array}$ & $\mathrm{K} 8, \mathrm{~K} 10, \mathrm{~K} 11$ & 3 & 13,63 \\
\hline & Rehberlerin anlatımlarını destekleyerek olumlu bir etki yaratacaktır & $\mathrm{K} 17, \mathrm{~K} 18$ & 2 & 9,09 \\
\hline & İnsanların beklentilerini karşılayabilecek bir uygulamalardır & K6 & 1 & 4,54 \\
\hline & Merak edilen her şey hakkında bilgi sağlayacaktır & K21 & 1 & 4,54 \\
\hline & $\begin{array}{l}\text { Merak ve nostalji duygusuna zarar verebilir; bunun sonucunda da } \\
\text { turist rehberlerinin anlatımlarına olumsuz yönde etki edebilir }\end{array}$ & $\mathrm{K} 3$ & 1 & 4,54 \\
\hline \multicolumn{3}{|l|}{ Toplam } & 22 & 100 \\
\hline
\end{tabular}

Turist rehberlerinin "Sizce bu uygulamaların turistlere olumlu ve olumsuz olmak üzere ne gibi etkileri olabilir?" sorusuna vermiş oldukları yanıtlar incelendiğinde; turist rehberlerinin \%81,81'i (K1, K2, K3, K4, K5, K6, K7, K9, K10, K11, K12, K13, K14, K17, K19, K20, K21, K22) olmak üzere büyük bir çoğunluğu, artırılmış gerçeklik uygulamalarının "turistler üzerinde faydalı bir biçimde olumlu bir etki bırakacă̆g" yönünde görüşlerini belirtmişlerdir. Bununla birlikte, 
K17 kodlu turist rehberi $(\% 4,54)$, artırılmış gerçeklik uygulamalarının turistler üzerinde olumlu etkilerde bulunacağına değinerek, onların "bilgilerinin artmasını să̆layacă̆ından" söz etmektedir. K8 kodlu turist rehberi (\%4,54), bu uygulamaların "turistlere verilen bilgileri tamamlayacağını" dile getirmiştir. K18 kodlu turist rehberi (\%4,54) ise bu uygulamaların "turistlerin memnuniyet düzeylerini arttıracă̆ına ve öğrenme açısından büyük katkı să̆layacă̆ına" değinmektedir. K15 ve K16 kodlu turist rehberlerinin $(\% 9,09)$ yönetilen soruya cevap vermemesinden dolayı görüşleri değerlendirilememiştir (Tablo 13).

Tablo 13. "Sizce bu uygulamaların turistlere olumlu ve olumsuz olmak üzere ne gibi etkileri olabilir?” Sorusuna Yönelik Yanıtlar

\begin{tabular}{|c|c|c|c|c|}
\hline Soru & Kodlar & Katılımcılar & $n$ & $\%$ \\
\hline \multirow{5}{*}{$\begin{array}{l}\text { Sizce bu } \\
\text { uygulamaların } \\
\text { turistlere olumlu ve } \\
\text { olumsuz olmak üzere } \\
\text { ne gibi etkileri } \\
\text { olabilir? }\end{array}$} & $\begin{array}{l}\text { Turistler üzerinde faydalı bir biçimde olumlu bir etki } \\
\text { bırakacaktır }\end{array}$ & $\begin{array}{l}\text { K1, K2, K3, K4, K5, K6, K7, K9, K10, K11, } \\
\text { K12, K13, K14, K17*, K19, K20, K21, K22 }\end{array}$ & 18 & 81,81 \\
\hline & Turistlerin bilgilerinin artmasını sağlayacaktır & K17* & 1 & 4,54 \\
\hline & Turistlere verilen bilgileri tamamlayacaktır & K8 & 1 & 4,54 \\
\hline & $\begin{array}{l}\text { Turistlerin memnuniyet düzeylerini arttıracağına ve } \\
\text { öğrenme açısından büyük katkı sağlayacaktır }\end{array}$ & K18 & 1 & 4,54 \\
\hline & Cevap alınamamıştır & K15, K16 & 2 & 9,09 \\
\hline \multicolumn{3}{|l|}{ Toplam } & 22 & 100 \\
\hline
\end{tabular}

Turist rehberlerine yöneltilen “Artırılmış gerçeklik uygulamalarının kullanımının geliştirilmesi için neler yapılmalıdır?” sorusuna vermiş oldukları yanıtlara bakıldığında; turist rehberlerinin \%22,72'si (K6, K17, K20, K21, K22), bu uygulamaların "daha çok tanıtımının yapılarak insanların bilgilendirilmesi gerekliliğine” değinmektedirler. K12, K18 ve K19 kodlu katılımcıların $(\% 13,63)$ ise "daha fazla araştırma ve yatırım yapılarak, ilgili kurum ve kuruluşların bu uygulamaların kullanımının arttırılmasını sağlaması gerekliliğine” işaret etmektedirler. Turist rehberlerinden K3 ve K4 kodlu katılımcıların $(\% 9,09)$, artırılmış gerçeklik uygulamalarının "gelişiminin zamana bırakılması" yönünde görüşlerini belirtmişlerdir. K8 kodlu turist rehberi $(\% 4,54)$, bu uygulamaların geliştirilmesi için "sağlam bir alt yapı olması gerektiğinden" söz etmektedir. Turist rehberlerinin \%50,0’sinin (K1, K2, K5, K7, K9, K10, K11, K13, K14, K15, K16), ilgili soruya yönelik yanıt vermemeleri nedeniyle görüşleri değerlendirilememiştir (Tablo 14).

Tablo 14. “Artırılmış gerçeklik uygulamalarının kullanımının geliştirilmesi için neler yapılmalıdır?” Sorusuna Yönelik Yanitlar

\begin{tabular}{|c|c|c|c|c|}
\hline Soru & Kodlar & Katılımcılar & $n$ & $\%$ \\
\hline \multirow{5}{*}{$\begin{array}{l}\text { Artırılmış gerçeklik } \\
\text { uygulamalarının } \\
\text { kullanımının } \\
\text { geliştirilmesi için neler } \\
\text { yapılmalıdır? }\end{array}$} & Daha çok tanıtımının yapılarak insanların bilgilendirilmesi gereklidir & K6, K17, K20, K21, K22 & 5 & 22,72 \\
\hline & $\begin{array}{l}\text { Daha fazla araştırma ve yatırım yapılarak, ilgili kurum ve kuruluşların } \\
\text { bu uygulamaların kullanımının arttırılmasını sağlaması gereklidir }\end{array}$ & $\mathrm{K} 12, \mathrm{~K} 18, \mathrm{~K} 19$ & 3 & 13,63 \\
\hline & Gelişiminin zamana bırakılması gereklidir & $\mathrm{K} 3, \mathrm{~K} 4$ & 2 & 9,09 \\
\hline & Sağlam bir alt yapı olması gerekmektedir & K8 & 1 & 4,54 \\
\hline & Cevap alınamamıştır & $\begin{array}{l}\mathrm{K} 1, \mathrm{~K} 2, \mathrm{~K} 5, \mathrm{~K} 7, \mathrm{~K} 9, \mathrm{~K} 10, \\
\mathrm{~K} 11, \mathrm{~K} 13, \mathrm{~K} 14, \mathrm{~K} 15, \mathrm{~K} 16\end{array}$ & 11 & 50,0 \\
\hline \multicolumn{3}{|l|}{ Toplam } & 22 & 100 \\
\hline
\end{tabular}

Artırılmış gerçeklik uygulamaları hakkında bilgi sahibi olan 22 turist rehberinden \%18,18'i (K1, K18, K19, K20) olmak üzere toplamda 4 katılımcı bu uygulamaların kullanımından memnun olduklarını belirtmektedirler. K17 kodlu turist rehberi $(\% 4,54)$, bu uygulamaları daha önce kullanmadığı için bir yorumda bulunmamıştır. K8 kodlu turist rehberi $(\% 4,54)$ ise bu uygulamaların kullanımının zor olması ve gerekli alt yapının sağlanamaması nedeniyle memnun olmadığını belirtmiştir. Diğer turist rehberleri $(\% 72,72)$ bu uygulamaların kullanımından memnun olup olmadıklarına ilişkin yöneltilen soruya yanıt vermemişlerdir (Tablo 15). 
Tablo 15. Turist Rehberlerinin Artırılmış Gerçeklik Kullanımına Yönelik Memnuniyet Durumu

\begin{tabular}{|c|c|c|c|c|}
\hline Soru & Kodlar & Katılımcılar & $n$ & $\%$ \\
\hline \multirow{3}{*}{$\begin{array}{l}\text { Artırılmış gerçeklik } \\
\text { uygulamalarının } \\
\text { kullanımından } \\
\text { memnun musunuz? }\end{array}$} & Memnunum & $\mathrm{K} 1, \mathrm{~K} 18, \mathrm{~K} 19, \mathrm{~K} 20$ & 4 & 18,18 \\
\hline & $\begin{array}{l}\text { Kullanımının zor olması ve gerekli alt yapının } \\
\text { sağlanamaması nedeniyle memnun değilim }\end{array}$ & K8 & 1 & 4,54 \\
\hline & Cevap alınamamıştır & $\begin{array}{l}\mathrm{K} 2, \mathrm{~K} 3, \mathrm{~K} 4, \mathrm{~K} 5, \mathrm{~K} 6, \mathrm{~K} 7, \mathrm{~K} 9, \mathrm{~K} 10, \mathrm{~K} 11, \mathrm{~K} 12, \mathrm{~K} 13, \\
\mathrm{~K} 14, \mathrm{~K} 15, \mathrm{~K} 16, \mathrm{~K} 17, \mathrm{~K} 21, \mathrm{~K} 22\end{array}$ & 17 & 77,27 \\
\hline \multicolumn{3}{|l|}{ Toplam } & 22 & 100 \\
\hline
\end{tabular}

Son olarak, artırılmış gerçeklik uygulamalarının kullanımını, turist rehberlerinin \%31,81'i (K1, K6, K12, K17, K18, K19, K20) olmak üzere toplamda 7 turist rehberi tavsiye etmektedir. K8 kodlu turist rehberi $(\% 4,54)$ ise bu uygulamaların kullanımını muhtemelen tavsiye edeceğini belirtmiştir (Tablo 16).

Tablo 16. Turist Rehberlerinin Artırılmış Gerçeklik Uygulamalarının Kullanımına Yönelik Tavsiye Etme Oranları

\begin{tabular}{|c|c|c|c|c|}
\hline Soru & Kodlar & Katılımcılar & $n$ & $\%$ \\
\hline \multirow{3}{*}{$\begin{array}{l}\text { Artırılmış gerçeklik } \\
\text { uygulamalarının } \\
\text { kullanımını tavsiye } \\
\text { eder misiniz? }\end{array}$} & Tavsiye ederim & K1, K6, K12, K17, K18, K19, K20 & 7 & 31,81 \\
\hline & Muhtemelen tavsiye ederim & K8 & 1 & 4,54 \\
\hline & Cevap alınamamıştır & $\begin{array}{l}\text { K2, K3, K4, K5, K7, K9, K10, K11, K13, K14, K15, K16, } \\
\text { K21, K22 }\end{array}$ & 14 & 63,63 \\
\hline \multicolumn{3}{|l|}{ Toplam } & 22 & 100 \\
\hline
\end{tabular}

\section{Sonuç ve Öneriler}

Turist rehberlerinin artırılmış gerçeklik uygulamalarına yönelik algılarının belirlenmesi amacıyla yapılan bu araştırmanın verileri, 100 turist rehberi üzerinden sağlanmıştır. Ancak, 100 turist rehberi içerisinden artırılmış gerçeklik uygulamaları ile ilgili bilgi sahibi olan 22 turist rehberinin bulunması nedeniyle, yalnızca söz konusu turist rehberlerinin görüşlerine danışılabilmiştir. Bu doğrultuda, turist rehberleri arasında artırılmış gerçeklik uygulamalarının bilinirlik düzeyinin düşük olduğu sonucuna ulaşılmıştır. İlgili turist rehberlerinin yapmış olduğu yorumlar ve açıklamalar doğrultusunda elde edilen veriler, kapsamlı bir şekilde incelenerek doğrudan alıntılarla birlikte analizlere tabi tutulmuştur.

Artırılmış gerçeklik uygulamaları ile ilgili bilgi sahibi olan 22 turist rehberinin sosyo-demografik özellikleri doğrultusunda cinsiyet değişkeni ele alındığında, kişi sayılarının birbirine yakın olduğu görülmektedir. Artırılmış gerçeklik uygulamalarının bilinirliğinde yaş faktörü göz önünde bulundurulduğunda, katılımcıların en çok 11 kişi olmak üzere 26-35 yaş aralığında olması nedeniyle, daha çok genç yaştaki turist rehberlerinin bu uygulamalar hakkında daha fazla bilgi sahibi olduğu söylenebilir.

Araştırma içerisinde değerlendirmeye tabi tutulan 22 turist rehberinin, bu uygulama hakkındaki bilgiyi en çok yazılı ve görsel medya yoluyla aldığı görülmektedir. Bu doğrultuda, çeşitli medya kanallarının bu uygulamalar hakkında bilgi sağlanmasında etkili bir faktör olduğu söylenebilir.

Turist rehberlerinin artırılmış gerçeklik ile ilgili yapmış oldukları tanımlamaların büyük bir bölümünün, bu uygulamaya yönelik alanyazında yapılmış tanımlamalarla (Milgram ve Kishino, 1994; Azuma, 1997; Höllerer ve Feiner, 2004; Bimber ve Raskar, 2005; Carmigniani ve Furth, 2011) benzerlik gösterdiği tespit edilmiştir. Bu doğrultuda, ilgili turist rehberlerinin bu uygulamalar hakkında yeterli düzeyde algılarının olduğu söylenebilir. Diğer yandan, K7, K13 ve K14 kodlu katılımcıların bu uygulamaları "sanal gerçeklik" olarak tanımladıkları görülmektedir. Ancak, artırılmış gerçeklik sanal gerçekliğin bir varyasyonu olan bir uygulamadır (Azuma, 1997). Sanal gerçeklik ve artırılmış gerçeklik kavramlarının birbirleriyle sürekli karıştırıldığı görülmektedir. Artırılmış gerçeklik, bilgisayar ortamında oluşturulan sanal enformasyonları gerçek fiziksel dünya görüntüsü üzerine aktaran ve birleştiren uygulamalardır (Carmigniani ve Furth, 2011). K10 kodlu katılımcı, "artırılmış gerçeklik uygulamalarının sağladığı bilgilere sanal ortamdan ulaşıldığına" değinmektedir. Ancak artırılmış gerçeklik uygulamaları kullanıcılarına bilgileri doğrudan sanal ortam üzerinden değil, gerçek ortam üzerine aktarılan sanal verilerle birlikte sağlamaktadır (Bimber ve Raskar, 2005).

Artırılmış gerçeklik uygulamalarını daha önce kullanan turist rehberi sayısının 5 kişiyle kısıtlı kalması, bu uygulamaların kullanımının yeterli düzeyde olmadı̆̆ını göstermektedir. İlgili turist rehberlerinin bu uygulamalara en çok internet üzerinden erişerek, turlarında materyal olarak kullandıkları görülmektedir. Turist rehberlerinin müze ve ören yerlerinde anlatımlarını gerçekleştirirken faydalı olacağı düşünülen artırılmış gerçeklik uygulamalarını yalnızca 2 turist rehberinin kullanması, turlarda bu uygulamalarının kullanımının oldukça düşük olduğunu göstermektedir. Buna ek olarak, 
turist rehberlerinin büyük bir kısmı, artıılmış gerçeklik uygulamalarının turlarda kullanımının yeterli düzeyde olmadığını belirtmişlerdir.

Araştırma kapsamındaki 22 turist rehberinin büyük bir çoğunluğu, tur süresince artırılmış gerçeklik uygulamalarının kullanımının, turistlerin anlatılan konulara olan ilgilerini arttırma ve kültürel değerlerin anlaşılmasına yardımcı olma noktasında önemli olduğuna değinmektedirler. İlgili alanyazında da artırılmış gerçeklik gibi teknolojik uygulamaların, kültürel değerlerin aktarılması, anlaşılması korunması hususunda oldukça önemli bir etkisinin olduğundan söz edilmektedir (Portales ve diğerleri, 2009; Muşkara, 2017). Bu doğrultuda, turist rehberlerinin büyük bir bölümünün artırılmış gerçeklik uygulamalarının önemi üzerinde durup faydalı uygulamalar olduğundan söz ederek, bu uygulamaların kullanımına karşı olumlu düzeyde bir yaklaşım gösterdikleri söylenebilir. Diğer yandan, K22 kodlu turist rehberi, artırılmış gerçeklik uygulamalarının "sanal ortamdan bilgi alınabilmesini sağladığını” belirtmiştir. Ancak daha önce de belirtildiği üzere, artırılmış gerçeklik, kullanıcılarına bilgileri doğrudan sanal ortam üzerinden değil, gerçek ortam üzerine aktarılan sanal verilerle birlikte sağlamaktadır (Bimber ve Raskar, 2005).

Artırılmış gerçeklik uygulamalarının hem turist rehberlerine hem de turistlere ne gibi olumlu veya olumsuz etkileri olabileceği konusunda, turist rehberlerinin büyük bir bölümü, rehberlerin vermiş olduğu bilgileri tamamlayarak işlerini kolaylaştırması, bunun sonucunda da turistlerin kültürel değerleri daha etkili bir biçimde anlamaları sağlanarak memnuniyet düzeylerini arttırması nedeniyle olumlu etkileri olabileceğine değinmektedirler. İlgili alanyazın incelendiğinde de artırılmış gerçeklik gibi teknolojik uygulamaların, turist rehberlerinin anlatımlarını pekiştirerek daha etkili bir anlatım yapabilmelerini ve turistlerin de kültürel değerlerin geçmişini daha iyi anlayarak memnun kalmalarını sağladığından söz edilmektedir (Vlahakis ve diğerleri, 2002; Tekin ve diğerleri, 2017). Buna karşın, K3 kodlu turist rehberi ise artırılmış gerçeklik uygulamalarının, "merak ve nostalji duygusuna zarar verebileceği; bunun sonucunda da turist rehberlerinin anlatımlarına olumsuz yönde etki edebileceği” şeklinde görüşlerini belirtmiştir.

Turist rehberleri artırılmış gerçeklik uygulamalarının geliştirilmesi için ilgili kurum ve kuruluşların daha fazla araştırma yaparak gerekli altyapıyı sağlaması ve daha fazla tanıtımın yapılarak insanların bilgilendirilmesi gerekliliği şeklinde görüşlerini belirtmişlerdir. Son olarak, artırılmış gerçeklik uygulamalarının turist rehberleri tarafından yoğun bir biçimde kullanılmaması gerekçesiyle, rehberlerinin bu uygulamalara yönelik memnuniyet düzeylerinin düşük olduğu ve bu uygulamaları tavsiye eden rehber sayısının da 7 kişiyle kısıtlı kaldığı düşünülmektedir.

Turist rehberlerinin artırılmış gerçeklik uygulamaları ile ilgili yapmış oldukları yorumların değerlendirilmesi ile elde edilen sonuçlar doğrultusunda, araştırmanın önerileri şu şekilde sıralanabilir:

Kültür ve Turizm Bakanlığı'na öneriler: Kültür ve Turizm Bakanlığı'nın artırılmış gerçeklik uygulamalarını geliştirebilecek ilgili kurum veya kuruluşlarla işbirliği içerisinde bulunarak, bu uygulamaların tanıtımı yapmaları ile birlikte müze ve kültürel miras alanlarında kullanımının teşvikini sağlamasının gerekli olduğu düşünülmektedir. Müzeler ve kültürel miras alanlarında kullanılmak amacıyla geliştirilen artırılmış gerçeklik uygulamalarına yönelik tanıtıcı broşürler veya kataloglar hazırlanarak, turist rehberleri ve turistlerin bilgilendirilerek bu uygulamaların tanıtımlarının yapılması önerilmektedir. Döner Sermaye İşletmesi Merkez Müdürlüğü’nün (DÖSIMM), müzeler ve ören yerleri gibi kültürel alanlarda kullanılmak üzere geliştirilebilecek artırılmış gerçeklik uygulamalarına yönelik, bütçe desteğini sağlamasının gerekli olduğu düşünülmektedir.

Türkiye Seyahat Acentaları Birliği'ne (TÜRSAB) öneriler: Seyahat acentaları tarafindan oluşturulan tur programlarında, özellikle tur programı kapsamında ziyaret edilecek müzeler ve ören yerleri gibi kültürel alanlarda, artırılmış gerçeklik uygulamalarının ilgili kurum veya kuruluşlarla birlikte işbirliği içerisinde bulunularak tur programlarına dahil edilip, rehberli turlarda kullanılması önerilebilir.

Turist Rehberleri Birliği (TUREB) ve Turist Rehberleri Odalarına öneriler: Müzeler ve ören yerleri gibi kültürel alanlarda turist rehberlerinin işini kolaylaştırabilecek ve anlatımlarına destek olacak nitelikteki artırılmış gerçeklik uygulamalarının rehberler tarafından kullanımının sağlanması konusunda, geliştirilen uygulamalar Turist Rehberleri Birliği'ne ve turist rehberleri odalarına tanıtımlarının yapılarak bilgilendirme sağlanmasının gerekli olduğu düşünülmektedir. Turist rehberlerine yönelik olarak yapılan meslekte uzmanlaşma programlarına benzer şekilde, teknolojik uygulamaları konu alan yeni eğitim programları oluşturulabilir.

Araştırmacılara ve geliştiricilere öneriler: Artırılmış gerçeklik gibi teknolojik uygulamaları geliştirebilecek ilgili kurum veya kuruluşların, bu uygulamaların özellikle müze ve kültürel miras alanlarında kullanımına yönelik yeterli düzeyde araştırma ve geliştirme yapmalarının gerekli olduğu düşünülmektedir. Araştırmacıların ve geliştiricilerin, artırılmış gerçeklik uygulamalarını müze ve kültürel miras alanlarında gerekli alt yapının sağlanarak, turist rehberleri ve turistlerin kullanabileceği düzeyde geliştirmelerini sağlamaları önerilebilir. Türkiye'de yer alan müzeler ve ören yerleri gibi kültürel alanlarda, artırılmış gerçeklik uygulamalarının geliştirilebileceği bölgeler ile yerler belirlenebilir ve belirlenen alanlarda projeler geliştirilebilir. Artırılmış gerçeklik uygulamalarının geliştirilmesinde, yurtdışında yapılmış araştırmalar ve çalışmalar doğrultusunda gerçekleşen projeler örnek alınarak, Türkiye'de özellikle müze ve ören yerleri gibi kültürel alanlarda bu uygulamaların geliştirilmesine yönelik araştırmalar yapılabilir.

Turist rehberlerine öneriler: Turist rehberlerinin anlatımlarını destekleyici ve zenginleştirici nitelikte olan artırılmış gerçeklik uygulamalarını, turistlerin kültürel değerleri daha iyi anlamaları ve memnuniyet düzeylerinin arttırılmasının sağlanması açısından, rehberler tarafından daha sık kullanması önerilmektedir.

Diğer araştırmacılara öneriler: İleride yapılacak olan çalışmalarda, artırılmış gerçeklik uygulamalarının yeterli yoğunlukta kullanımının yaygınlaşmasıyla birlikte, özellikle rehberli turlarda bu uygulamaları deneyimleyen turistlerin memnuniyet düzeylerinin ölçülmesi önerilebilir. 
Şalk, S., Köroğlu, Ö. / Journal of Yasar University, 2020, 15/58, 313-328

\section{KAYNAKÇA}

Ahipaşaoğlu, H. Suavi. (2006). Turizmde Rehberlik. Gözden Geçirilmiş II. Baskı. Ankara: Gazi Kitabevi.

Azuma, Ronald T. (1997). A Survey of Augmented Reality. Presence: Teleoperators and Virtual Environments, 6 (4), 355-385.

Azuma, Ronald, Yohan Baillot, Reinhold Behringer, Steven Feiner, Simon Julier and Blair MacIntyre. (2001). Recent Advances in Augmented Reality. IEEE Computer Graphics and Applications. 21 (6), 34-47.

Bal, Hüseyin. (2016). Nitel Araştırma Yöntem ve Teknikleri (Uygulamall-Örnekli). 1. Basım, İstanbul: Sentez Yayınları.

Billinghurst, Mark, Adrian Clark and Gun Lee. (2014). A Survey of Augmented Reality. Foundations and Trends in Human - Computer Interaction. 8 (2-3), 73-272.

Bimber, Oliver and Ramesh Raskar. (2005). Spatial Augmented Reality: Merging Real and Virtual Worlds. Massachusetts: A. K. Peters, Ltd. Natick.

Bower, Matt, Cathie Howe, Nerida McCredie, Austin Robinson and David Grover. (2014). Augmented Reality in Education - Cases, Places and Potentials, Educational Media International, 51 (1), 1-15.

Boyraz, Burak. (2013). Müze Teknolojileri ve Sergileme Farklılıkları. İdil Dergisi, 2 (8), 113-128.

Carmigniani, Julie and Borko Furth. (2011). Augmented Reality: An Overview. Furth, Borko (Editor). Handbook of Augmented Reality. New York: Springer Science+Business Media, pp. 3-46.

Coşkun, Recai, Remzi Altunışık, Serkan Bayraktaroğlu ve Engin Yıldırım. (2015). Sosyal Bilimlerde Araştırma Yöntemleri Spss Uygulamalı. 8. Baskı, Adapazarı: Sakarya Kitabevi.

Çakmak, Tolga Fahri ve Şehnaz Demirkol. (2017). Teknolojik Gelişmelerin Turist Rehberliği Mesleğine Etkileri Üzerine Bir Swot Analizi. Bingöl Üniversitesi Sosyal Bilimler Enstitüsü Dergisi, 7, 221-235.

Devlet Planlama Teşkilatı. (2001). Bilişim Teknolojileri ve Politikaları Özel İhtisas Komisyonu Raporu. Sekizinci Beş Yıllık Kalkınma Planı, Ankara.

Dönmezoğlu, Deniz. (2013). Günümüz Müzeciliğinde Sergileme Tekniklerinin Sanal Teknolojiler ile Desteklenmesi ve Uygulama Örnekleri. Yayınlanmamış Uzmanlık Tezi. T.C. Kültür ve Turizm Bakanlığı Kültür Varlıkları ve Müzeler Genel Müdürlüğ̈̈, Ankara.

Güler, Ahmet, Mustafa Bülent Halıcıoğlu ve Serkan Taşğın. (2015). Sosyal Bilimlerde Nitel Araştırma. Genişletilmiş ve Gözden Geçirilmiş 2. Baskı, Ankara: Seçkin Yayıncılık.

Güzel, F. Özlem (2007). Türkiye Imajının Geliștirilmesinde Profesyonel Turist Rehberlerinin Rolü (Alman Turistler Üzerine Bir Araştırma). Yayınlanmamış Yüksek Lisans Tezi. Balıkesir Üniversitesi Sosyal Bilimler Enstitüsü, Balıkesir.

Han, Dai-In, Timothy Jung and Alex Gibson. (2014). Dublin AR: Implementing Augmented Reality in Tourism. Z. Xiang and I. Tussyadiah (Editors). Information and Communication Technologies in Tourism 2014, Springer, Cham, pp. 511-523.

Harmankaya, Mustafa Barış. (2010). Müzelerde Elektronik Rehberlik Uygulamaları. Yayınlanmamış Uzmanlık Tezi. T.C. Kültür ve Turizm Bakanlığı Kültür Varlıkları ve Müzeler Genel Müdürlüğü, İstanbul.

Höllerer, Tobias H. and Steven K. Feiner. (2004). Mobile Augmented Reality. H. Karimi and A. Hammad (Editors). Telegeoinformatics: Location-Based Computing and Services, CRC Press, pp. 392-421.

Ioannidis, Yannis, Olivier Ballet and Dimitrios Pandermalis. (2014). Tell Me a Story: Augmented Reality Technology in Museums. Web: https://www.theguardian.com/culture-professionals-network/culture-professionalsblog/2014/apr/04/story-augmented-reality-technology-museums adresinden 09.08.2018 tarihinde alınmıştır.

Johnson, L., A. Levine, R. Smith and S. Stone. (2010). The 2010 Horizon Report. Austin, Texas: The New Media Consortium.

Kan, Tai-Wei, Chin-Hung Teng, and Mike Y. Chen. (2011). QR Code Based Augmented Reality Applications. Furth, Borko (Editor). Handbook of Augmented Reality. New York: Springer Science+Business Media, pp. 339-354.

Karatay, Ayşe. (2015). Artırllmış Gerçeklik Teknolojisi ve Müze İçi Eser Bilgilendirme ve Tanıtımlarının Artırılmış Gerçeklik Teknolojisi Yordamıyla Yapılması. Yayınlanmamış Yüksek Lisans Tezi, Dumlupınar Üniversitesi Sosyal Bilimler Enstitüsü, Kütahya.

Kenteris, Michael, Damianos Gavalas, and Daphne Economou. (2010). Electronic Mobile Guides: A Survey. Personal and Ubiquitous Computing, 15, 97-111.

Kipper, Gregory and Joseph Rampolla. (2013). Augmented Reality: An Emerging Technologies Guide to AR. Massachusetts: Syngress Media.

Kozak, Metin. (2015). Bilimsel Arasstırma: Tasarım, Yazım ve Yayım Teknikleri. 2. Baskı, Ankara: Detay Yayıncılık.

Köroğlu, Özlem. (2011). Müze ve Ören Yerlerinde Profesyonel Turist Rehberlerine Alternatif Olarak Elektronik Rehber Kullanımının Değerlendirilmesi. 1. Uluslararası Turizm ve Otelcilik Sempozyumu, (29 Eylül - 1 Ekim 2011), 209-218.

Köroğlu, Özlem. (2013). Turist Rehberlerinin İş Yaşamındaki Rolleri Üzerine Kavramsal Bir Değerlendirme. Pamukkale Üniversitesi Sosyal Bilimler Enstitüsü Dergisi, 16, 91-112.

Kuşluvan, Salih ve Nihat Çeşmeci. (2002). Türkiye'de Turist Rehberliği Eğitiminin Sorunları ve Yeniden Yapılandırlması. Turizm Eğitimi Konferansı-Workshop (11-13 Aralık 2002) Bildiriler Kitabı, Ankara: Turizm Bakanlığı, Turizm Eğitim Genel Müdürlüğü, 235-242.

Lee, Kangdon. (2012). Augmented Reality in Education and Training. TechTrends, 56 (2), 13-21. 
Mesleki Yeterlilik Kurumu, Ulusal Meslek Standard,, Profesyonel Turist Rehberi Seviye 5. (16.07.2010). Resmi Gazete, 27643.

Milgram, Paul and Fumio Kishino. (1994). A Taxonomy of Mixed Reality Visual Displays. IEICE Transactions on Information System, 77 (12), 1-15.

Muşkara, Üftade. (2017). Yeni Medyanın Kültürel Miras Konulu Uygulamaları. Erdem İnsan ve Toplum Bilimleri Dergisi, 73, 89-110.

Özgüneş, Reşad Emre ve Düriye Bozok. (2017). Turizm Sektörünün Sanal Rakibi (mi?): Artırılmış Gerçeklik. 1st International Sustainable Tourism Congress, (23-25 November 2017), 619-630.

Pence, Harry E. (2010). Smartphones, Smart Objects, and Augmented Reality, The Reference Librarian, 52 (1-2), 136145.

Sarı, Yaşar ve Metin Kozak. (2005). Turizm Pazarlamasında İnternetin Etkisi: Destinasyon Web Siteleri İçin Bir Model Önerisi. Akdeniz İ.I.B.F. Dergisi, 9, 248-271.

Sayımer, İdil ve Banu Küçüksaraç. (2015). Yeni Teknolojilerin Üniversite Eğitimine Katkısı: İletişim Fakültesi Öğrencilerinin Artırılmış Gerçeklik Uygulamalarına İlişkin Görüşleri. Internatoional Journal of Human Sciences, 12 (2), 1536-1554.

Styliani, Sylaiou, Liarokapis Fotis, Kotsakis Kostas and Patias Petros. (2009). Virtual Museums, A Survey and Some Issues for Consideration. Journal of Cultural Heritage, 10 (4), 520-528.

Tekin, Özlem, Müjde Bideci ve Ayla Aydın. (2015). Kültürel Mirasın Aktarımında Mobil Rehber Uygulamaları ile Profesyonel Turist Rehberlerinin Yetkinliğinin Karşılaştırması (Konya Mevlana Müzesi Örneği). I. Eurasia International Tourism Congress: Current Issues, Trends, and Indicators (EITOC-2015), 679-686.

Tekin, Özlem, Müjde Bideci ve Cevdet Avcıkurt. (2017). Turist Rehberliğinde Yeni Teknolojilerin Kullanımı. Güzel, F. Özlem, Volkan Altıntaş ve İlker Şahin (Editörler). Turist Rehberliği Araştırmaları Öngörüler ve Uygulamalar. Ankara: Detay Yayınc1lik, 291-303.

Tetik, Nuray. (2006). Türkiye'de Profesyonel Turist Rehberliği ve Müssterilerin Turist Rehberlerinden Beklentilerinin Analizi (Kuşadası Örneği). Yayınlanmamış Yüksek Lisans Tezi, Balıkesir Üniversitesi Sosyal Bilimler Enstitüsü, Balıkesir.

Van Krevelen, D. W. F. and Ronald Poelman. (2010). A Survey of Augmented Reality Technologies, Applications and Limitations. The International Journal of Virtual Reality, 9 (2), 1-20.

Vlahakis, Vasilios, Nikolaos Ioannidis, John Karigiannis, Manolis Tsotros, Michael Gounaris, Didier Stricker, Tim Gleue, Patrick Daehne and Luís Almeida. (2002). Archeoguide: An Augmented Reality Guide for Archaeological Sites. Computer Graphics in Art History and Archaeology, 22 (5), 52-60.

Web: http://tureb.org.tr/tr/RehberIstatistik/ adresinden 14.11.2018 tarihinde alınmıştır.

Web: http://www.chessexperience.eu/ adresinden 13.10.2018 tarihinde alınmıştır.

Web: https://www.blippar.com/blog/2017/11/06/welcome-ar-city-future-maps-and-navigation adresinden 09.08.2018 tarihinde alınmıştır.

Web: https://www.pcmag.com/encyclopedia/term/64233/smartphone-features adresinden 15.10 .2018 tarihinde alınmış̧ır.

Wojciechowski, Rafal, Krzysztof Walczak, Martin White and Wojciech Cellary (2004). Building Virtual and Augmented Reality Museum Exhibitions. Proceedings of the Ninth International Conference on 3D Web Technology (5-8 April 2004), Proceedings, 135-144.

Yıldırım, Ali ve Hasan Şimşek. (2016). Sosyal Bilimlerde Nitel Araştırma Yöntemleri. Genişletilmiş 10. Baskı, Ankara: Seçkin Yayıncılık San. ve Tic. A.Ş.

Yoon, Susan A., Karen Elinich and Joyce Wang. (2012). Using Augmented Reality and Knowledge-Building Scaffolds to Improve Learning in a Science Museum. Computer-Supported Collaborative Learning, 7, 519-541.

Yovcheva, Zornitza, Dimitrios Buhalis and Christos Gatzidis. (2012). Overview of Smartphone Augmented Reality Applications for Tourism. e-Review of Tourism Research (eRTR), 10 (2), 63-66.

Zachary, Wayne, Joan Ryder, James Hicinbothom and Kevin Bracken. (1997). The Use of Executable Cognitive Models in Simulation-Based Intelligent Embedded Training. Proceedings of Human Factors Society 41st Annual Meeting. 41 (2), 1118-1122.

Zhou, Yajin, Xinwen Zhang, Xuxian Jiang and Vincent W. Freeh. (2011). Taming Information-Stealing Smartphone Applications (on Android). In: McCune J.M., Balacheff B., Perrig A., Sadeghi AR., Sasse A. and Beres Y. (Editors) Trust and Trustworthy Computing. Trust 2011. Lecture Notes in Computer Science, vol 6740. Berlin, Heidelberg: Springer, pp. 93-107.

Zhu, Wei, Charles B. Owen, Hairong Li and Joo-Hyun Lee. (2004). Personalized In-store E-Commerce with the PromoPad: an Augmented Reality Shopping Assistant. Electronic Journal for E-commerce Tools and Applications, 1(3), 1-19. 